\title{
Synthesis of Spirooxoindole Derivatives
}

Mahmoud Refaee Mahmoud, Mahmoud Fawzy Ismail*

Chemistry Department, Faculty of Science, Ain Shams University, Abbassia, Cairo, Egypt, post code 11566.

*E-mail: fawzy2010@sci.asu.edu.eg

\section{ABSTRACT}

This review summarizes the methods for preparing spirocyclic oxoindole derivatives in the past years until 2012 which are divided into several groups according to ring size of the fused spiroindoles.

\section{Council for Innovative Research}

Peer Review Research Publishing System

Journal: Journal of Advances in Chemistry

Vol. 7, No. 1

editor@cirworld.com

www.cirworld.com, member.cirworld.com 


\section{INTRODUCTION}

Spirocyclic system containing one $\mathrm{sp}^{3}$ carbon atom common to two rings are structurally interesting ${ }^{[1]}$. The a symmetric structure of the molecule due to the chiral spiro carbon atom is one of the important criteria of the biological activities ${ }^{[2,3]}$. The presence of the sterically constrained spiro structure in various natural products also adds to the interest in the investigations of spiro compounds ${ }^{[4]}$. Similarly, functionalized spirocycloalkyl oxoindoles are found in a variety of natural products and bioactive molecules ${ }^{[5,6]}$.

Hence, a number of synthetic methods have been developed for expedition of these structural frame works ${ }^{[7-25]}$.

Moreover, some indolines, spiro-annulated with heterocycles in the position 3 , have shown high biological activity $[26-28]$
$[21,24,29-75]$ Therefore, a number of methods have been reported for the preparation of spirooxoindole fused heterocycles

\section{A) SPIRO[THREE-MEMBERED RING]OXOINDOLES}

\section{i. Spirocyclopropane oxoindole derivatives}

Oxindolylacrylates 1 react with diazomethane in a regioselective manner, depending on the substituent attached to the carbon atom $\alpha$ to the ester carbonyl group. In non-substituted acrylates, the 1,3-dipolar cycloaddition occurs furnishing ethyl-2-oxo-4',5'-dihydrospiro[indoline-3,3'-pyrazole]-4'-carboxylate 2 which, upon heating, losses $\mathrm{N}_{2}$ to give a spiro cyclopropane indolinone derivative $3^{[76,77]}$. (Scheme 1)<smiles>CCOC(=O)C1C(=O)Nc2ccccc21</smiles>

(1)

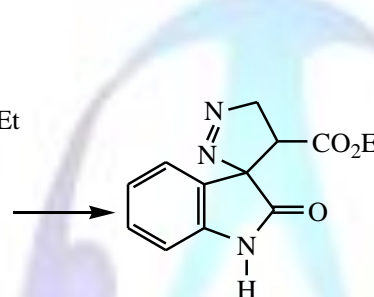

(2)<smiles>CCOC(=O)C1CC12C(=O)Nc1ccc(C)cc12</smiles>

(3)

Scheme 1: synthesis of spirocyclopropane oxoindole derivative 3

Similary, $\mathrm{N}$-protected isatin derivative $\mathbf{4}$ when treated with diazomethane afforded the spirocyclopropane indolinone derivative $5^{[76,78,79]}$.

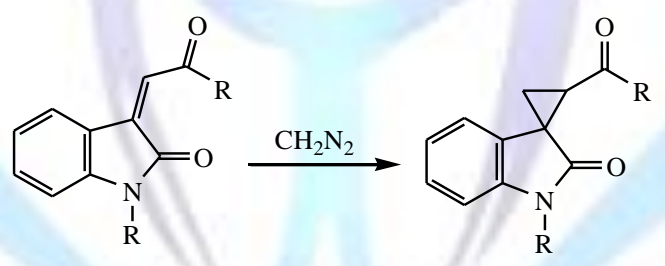

(4)

(5)

A facile, high yield stereoselective synthesis of functionalized diastereomeric 3-spirocyclopropane-2-indolones $\mathbf{9}$, 10 from the isomerised bromo derivatives of Baylis-Hillman adducts of isatin $7, \mathbf{8}$ by reductive cyclization with sodium borohydride is reported ${ }^{[80]}$. (Scheme 2,3 ) 


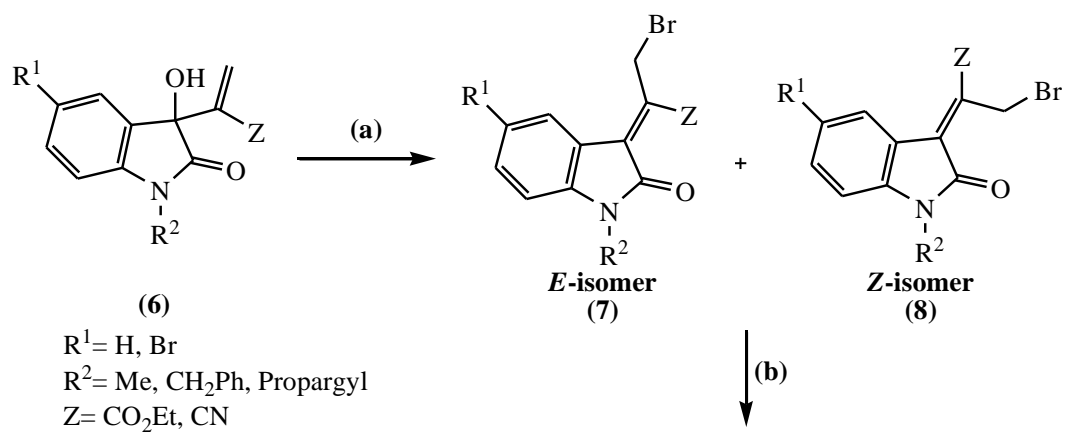

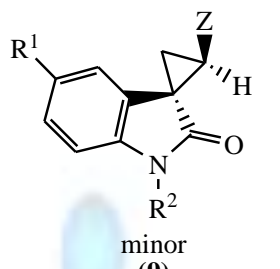

(9)

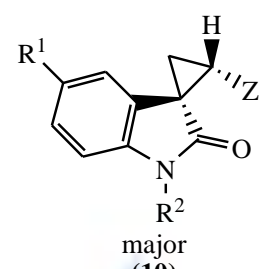

(10)

Scheme 2. Generality of the cyclopropanation. a) 4 equiv. $46 \% \mathrm{HBr}$, silica gel, $\mu \mathrm{w}, 750 \mathrm{~W}, 3 \mathrm{~min}$; b) 2 equiv. $\mathrm{NaBH}_{4}$, THF, $0.5 \mathrm{~h}$.<smiles>[Z]/C(CBr)=C1/C(=O)N([R])c2ccc([R])cc21</smiles>

E-isomer

(7)

or<smiles>[R]c1ccc2c(c1)/C(=C/C(C)CBr)C(=O)N2[R]</smiles>

$Z$-isomer

(8)<smiles>[R]c1ccc2c(c1)[C@@]1(C[C@@H]1[Z])C(=O)N2[R]</smiles>

minor

(9)

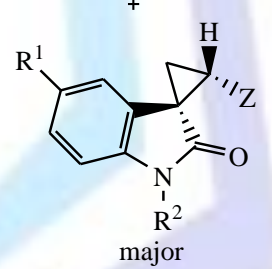

(10)

Scheme 3. A plausible mechanism for cyclopropanation.

A novel magnesium iodide mediated unusual dimerization-spirocyclopropanation of bromo isomerised MoritaBaylis-Hillman adducts of isatin afforded highly functionalized 3-spirocyclopropane-2-oxindole derivatives 11, 12 as regioisomers in good combined yield. It has been observed that the regioselectivity is dependent on the nature of electron withdrawing group at the activated position. A plausible mechanism involving organomagnesium reagent has been proposed $^{[8]]}$. (Scheme 4, 5) 

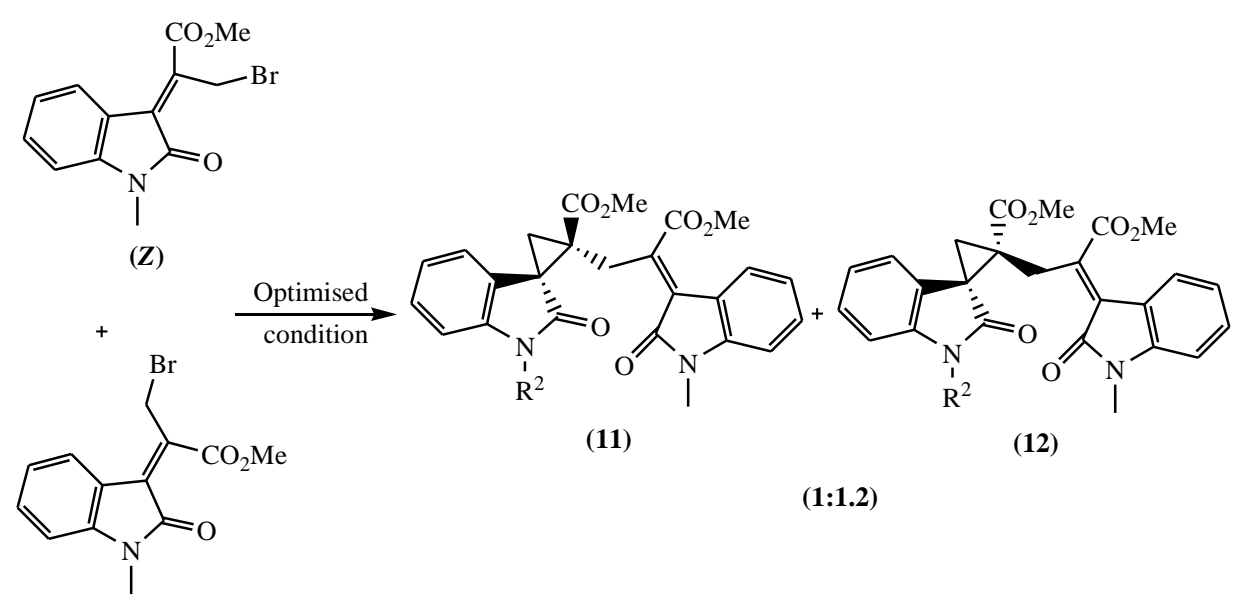

(11)

(12)

(1:1.2)

Scheme 4. Synthesis of spirocyclopropane derivatives of oxindole 11 and 12 from $Z$ and $E$ isomers.<smiles>[Z]C(I)=C1C(=O)N(C)c2ccccc21</smiles>

Z-isomer

(8)<smiles>[Y10]C=C1C(=O)N(C)c2ccccc21</smiles>

$\downarrow$

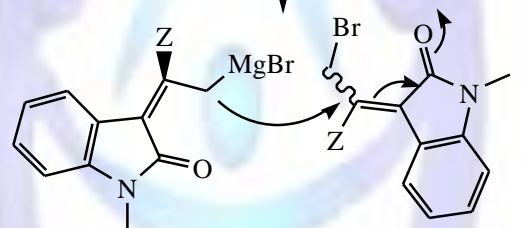

(B)

(A)
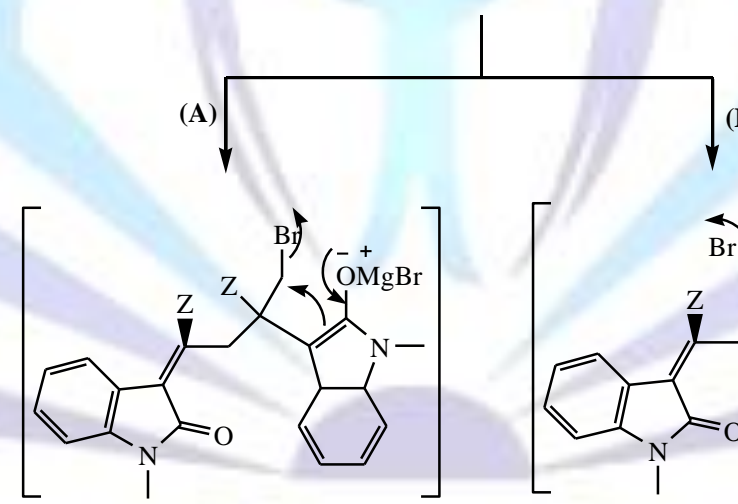

E-I

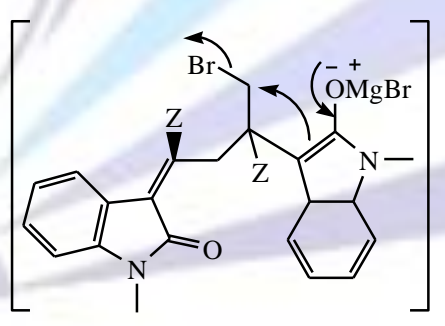

E-II
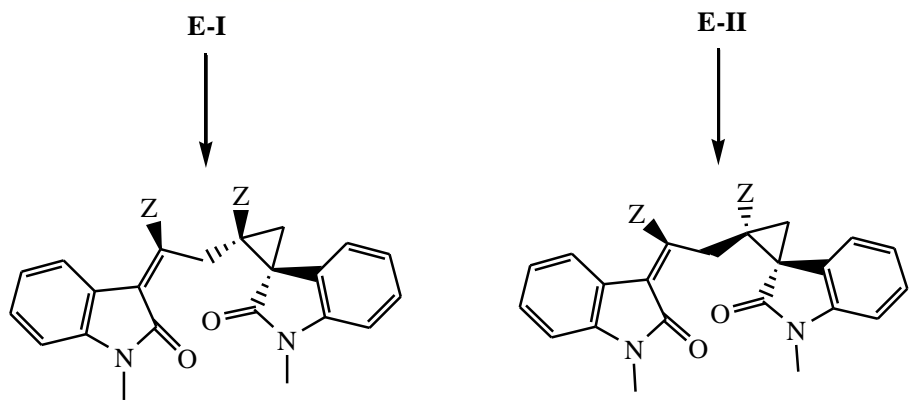

(11)

(12)

(1:1.2)

Scheme 5. Proposed mechanism for the formation of 11 and 12. 


\section{ii. Spirooxirane oxoindole derivatives}

Reaction of isatin with phenacyl bromide, either under conventional heating or in the MW promoted reaction, leads to $\mathrm{N}$-substituted derivative $\mathbf{1 3}$ in acceptable yields, although the MW procedure provided the best results. Variable amounts of spirooxirane oxoindole 14 , resulting from addition of the halomethylketone anion $\mathbf{A}$ onto the isatin $\beta$-carbonyl and further cyclization were obtained as a side product ${ }^{[82]}$. (Scheme 6)<smiles>O=C(CN1C(=O)C(=O)c2ccccc21)c1ccccc1</smiles>

(13)<smiles>O=C1Nc2cc[cH+]ccc2C1C(=O)c1ccccc1</smiles>

(14)<smiles>O=C1Nc2ccccc2C1=O</smiles>

Scheme 6. Probable mechanism for the synthesis of epoxide.

The o-methylether of isatin $\mathbf{1 5}$ reacts with diazomethane to furnish a quinoline derivative as the major product, together with a spirooxirane derivative $16^{[83]}$. (Scheme 7)<smiles>COC1=Nc2ccccc2C1=O</smiles>

(15)<smiles>CN(C)c1ccc2c(c1)C([O-])(C[NH])C(O)=N2</smiles><smiles>C=CC(=C)C</smiles>

(16)

$(15 \%)$

\section{Scheme 7}

\section{iii. Spiroaziridine oxoindoles}

1-(4-Aryl thiazol-2-yl)spiro aziridine-2,3'-indolin-2'-one 18 was synthesized from the reaction of 3-(4-aryl thiazol-2yl imino)indolin-2-one 17 with diazomethane ${ }^{[84]}$.

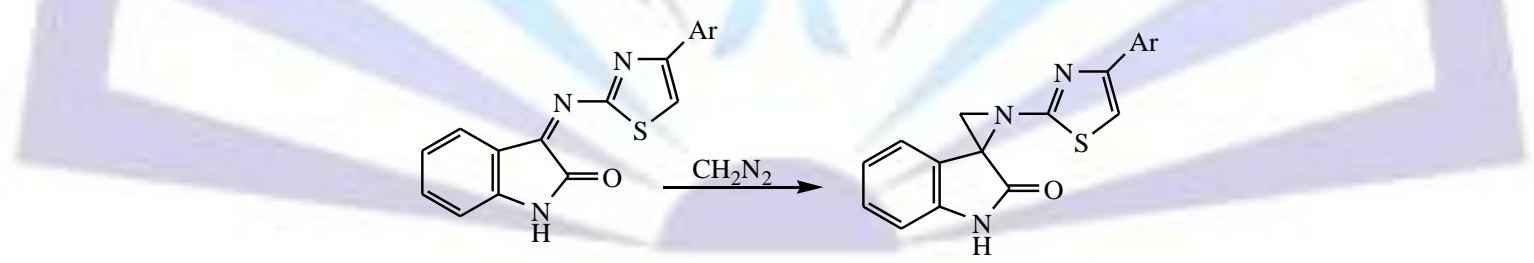

(17)

(18)

\section{B) SPIRO[FOUR-MEMBERED RING]OXOINDOLES}

\section{i. Spirocyclobutane oxoindole derivative}

Spiro cyclobutane oxoindole 19 was obtained by treatment of 1-methyl-3-(2-oxopropylidene)indolin-2-one 4 with ethylene diamine derivative ${ }^{[85]}(40-97 \%)$.<smiles>CC(=O)/C=C1\C(=O)Nc2ccccc21</smiles>

(4)

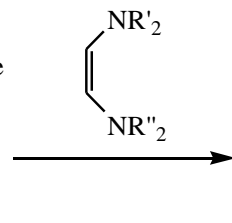

C<smiles>[R12]NC1C([Y12])C(C(C)=O)C12C(=O)Nc1ccccc12</smiles>

(19) 


\section{ii. Spirooxetane oxoindoles}

2-Ethoxy-3-indolone 20 suffers a thermal [2+2] cycloaddition with 1,1-dimethoxyethene, leading to an 2-ethoxy4',4'-dimethoxy spiro[indole-3,2'-oxetane] $21^{[86]}$.

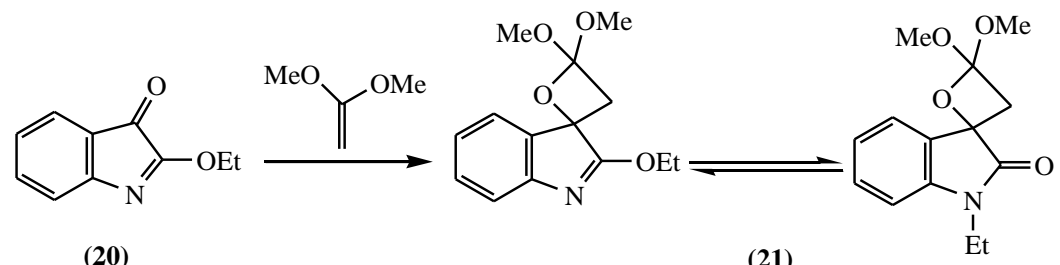

\section{iii. Spiroazitidine oxoindoles}

The spiro-fused 2-azetidinones constitute a scarce class of compounds. There are only a few reports in the literature on the synthesis, reactivity and biological activity of such 2 -azetidinones ${ }^{[87-102]}$. New 1-alkyl/cyclohexyl-3,3-diaryl1'-methyl spiro[azetidine-2,3'-indoline]-2',4-diones $\mathbf{2 4}$ have been synthesized from the reaction of the 2-diazo-1,2-diaryl ethanones 22 with 1-methyl-3-(alkyl/cyclohexyl imino)indoline-2-ones 23 under thermal condition ${ }^{\text {[103-106] }}$. (Scheme 8)

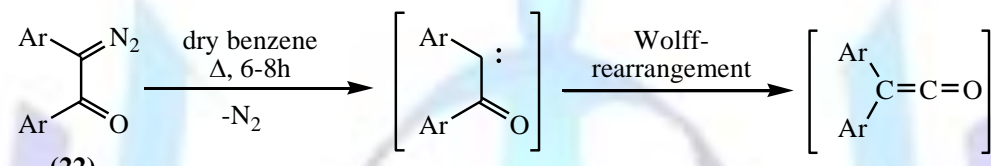

(22)

$\mathrm{Ar}=\mathrm{Ph}, 4-\mathrm{MeC}_{6} \mathrm{H}_{4}, 4-\mathrm{MeOC}_{6} \mathrm{H}_{4}$ $\mathrm{R}=\mathrm{CHMe}_{2}, \mathrm{CHPh}_{2}, \mathrm{CH}(\mathrm{Me}) \mathrm{Ph}$

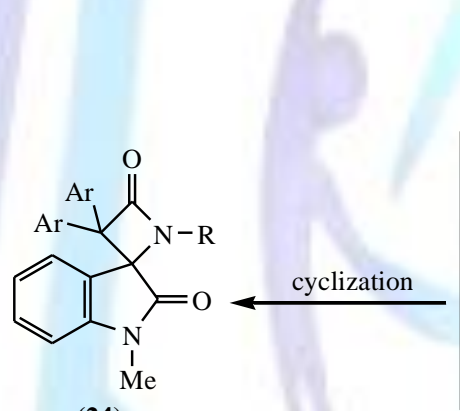

(24)

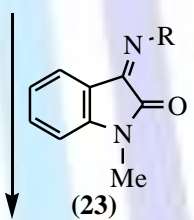

Scheme 8. Mechanism of formation of compounds 24.

Condensation of $\mathrm{N}$-substituted isatin with aromatic amines then acyl chloride yielded the spiroazetidine derivatives $25^{[93,107]}$
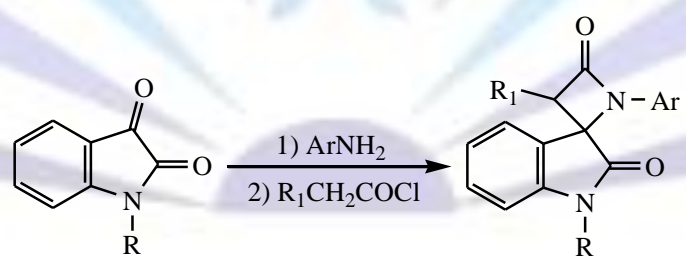

(25)

2-Amino-11-hydronaptho[2,1:5,6]pyrano[4,3- $d$ thiazole 26 on treatment with isatin, chloroacetyl chloride affords corresponding $N$-[naphtha[1,2-b]pyrano[3,4- $d$ ] thiazol-8-yl]spiro[3H-indole $(1 H, 2 H) 3,4-(2 H) 3$-chloroazetidine-2,2-diones 27 $[108,109]$. (Scheme 9)<smiles>Nc1nc2c(s1)C(Br)Oc1cc3ccccc3cc1-2</smiles>

(26)<smiles>O=C1Nc2ccccc2C1=O</smiles><smiles>O=C(Cl)CCl</smiles>

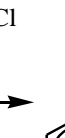<smiles>c1ccc2ccccc2c1</smiles>

(27)

Scheme 9 


\section{C) SPIRO[FIVE-MEMBERED RING]OXOINDOLES}

\section{i. Spirocyclobutane oxoindole derivative}

Recently, ${ }^{[110,111]}$ it was reported a novel phosphorus-containing lewis base catalyzed highly geometric selective $[3+2]$ annulation of isatin derived $\alpha, \beta$-unsaturated diesters 28, 29 with $\alpha$-allenic ester 30, 31 affording functionalized spiro cyclopentane indolinone derivatives 32-35. (Scheme 10)

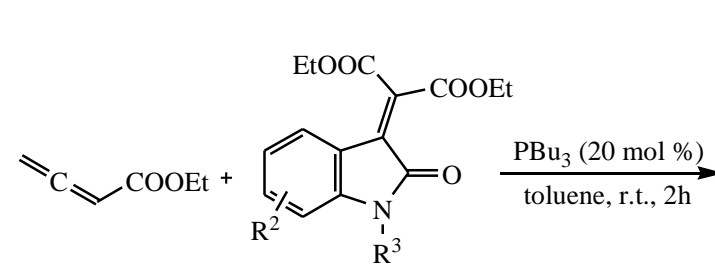

(30)
(28)<smiles>[R2]c1cccc2c1N([R])C(=O)[C@]21C(C(=O)OCC)=CCC1(C(=O)OCC)C(=O)OCC</smiles>

(32)<smiles>[R]c1cccc2c1N([R])C(=O)[C@]21CC=C(C(=O)OCC)C1(C)OCC</smiles>

(33)

(major)

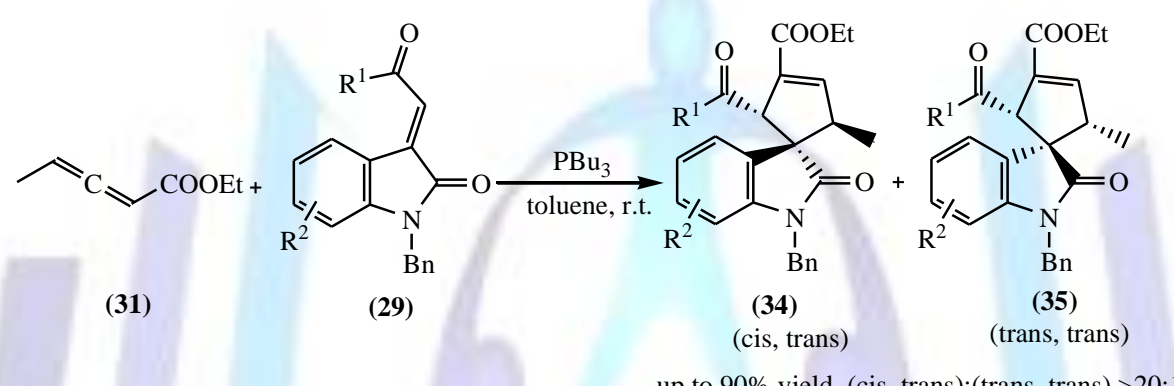

\section{Scheme 10}

2-(2-Oxoindolin-3-ylidene)acetic acid 36 under Friedel-Craft's conditions with benzene in anhydrous aluminium chloride afforded spiro[indene-1,3'-indoline]-2',3-(2H)dione $37^{[112]}$.<smiles>O=C(Cl)/C=C1\C(=O)Nc2ccccc21</smiles>

(36)

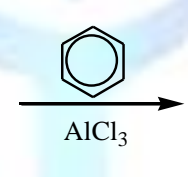<smiles>CC1(C)C(=O)Nc2ccccc21</smiles>

(37)

$(60 \%)$

\section{ii. Spirofurane oxoindole}

Oxindoles functionalised at C3 as spirolactones, ${ }^{[113-116]}$ spirocyclicethers and spirocarbo- and heterocyclics are elegant targets in organic synthesis due to their significant biological activities

The reaction of Morita-Baylis-Hillman adduct of $\mathrm{N}$-methylisatin 6 with excess of trimethyl orthoformate and montmorillonite $\mathrm{K} 10$ clay ${ }^{[120-123]}$ catalyst at $110{ }^{\circ} \mathrm{C}$ for $0.5 \mathrm{~h}$ afforded a $1: 3$ mixture of $E$ - and Z-isomer $\mathbf{4 0}$ and $\mathbf{4 1}$ with overall yield $(75 \%)^{[124]}$. (Scheme 11) 


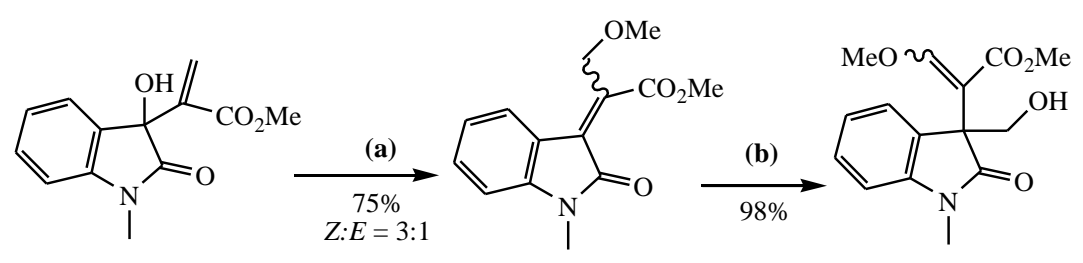

(6)

(38)

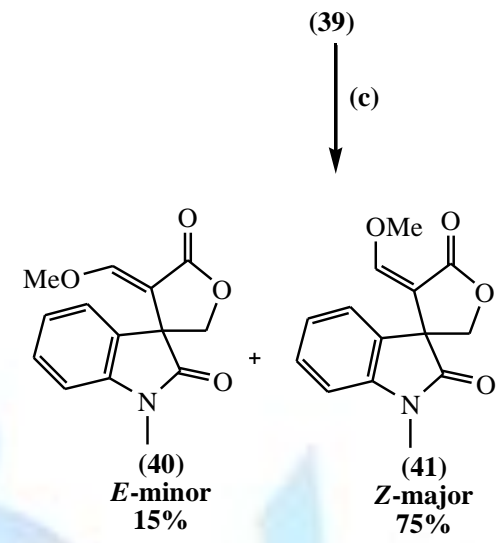

Scheme 11. Synthesis of 3-spiro- $\alpha$-methylene- $\mathrm{\gamma}$-butyrolactone- $\mathrm{N}$-methyl oxindoles 40 and 41 . a) $\mathrm{CH}(\mathrm{OMe})_{3} / \mathrm{Mont}$. $\mathrm{K} 10$, neat, $110^{\circ} \mathrm{C}, 30 \mathrm{~min}$; b) aq. HCHO, DABCO, r.t., acetone, $1.5 \mathrm{~h}$; c) PTSA/benzene, $30 \mathrm{~min}$.

Novel phosphorus-containing lewis bases catalyzed [3+2] annulation of isatin $\mathbf{4 2}$ with but-3-yn-2-one $\mathbf{4 3}$ giving the corresponding spiro[furan-2,3'-indoline]2',4-(5H)dione 44 in excellent yields under mild conditions ${ }^{[125]}$. Moreover, the reaction of $\mathbf{4 2}$ with ethyl-2-bromomethylacrylate with zinc under Refrrmatisky type reaction gave the spiro[furan-2,3'indoline]2',5-(4H)dione $45^{[126]}$. (Scheme 12)

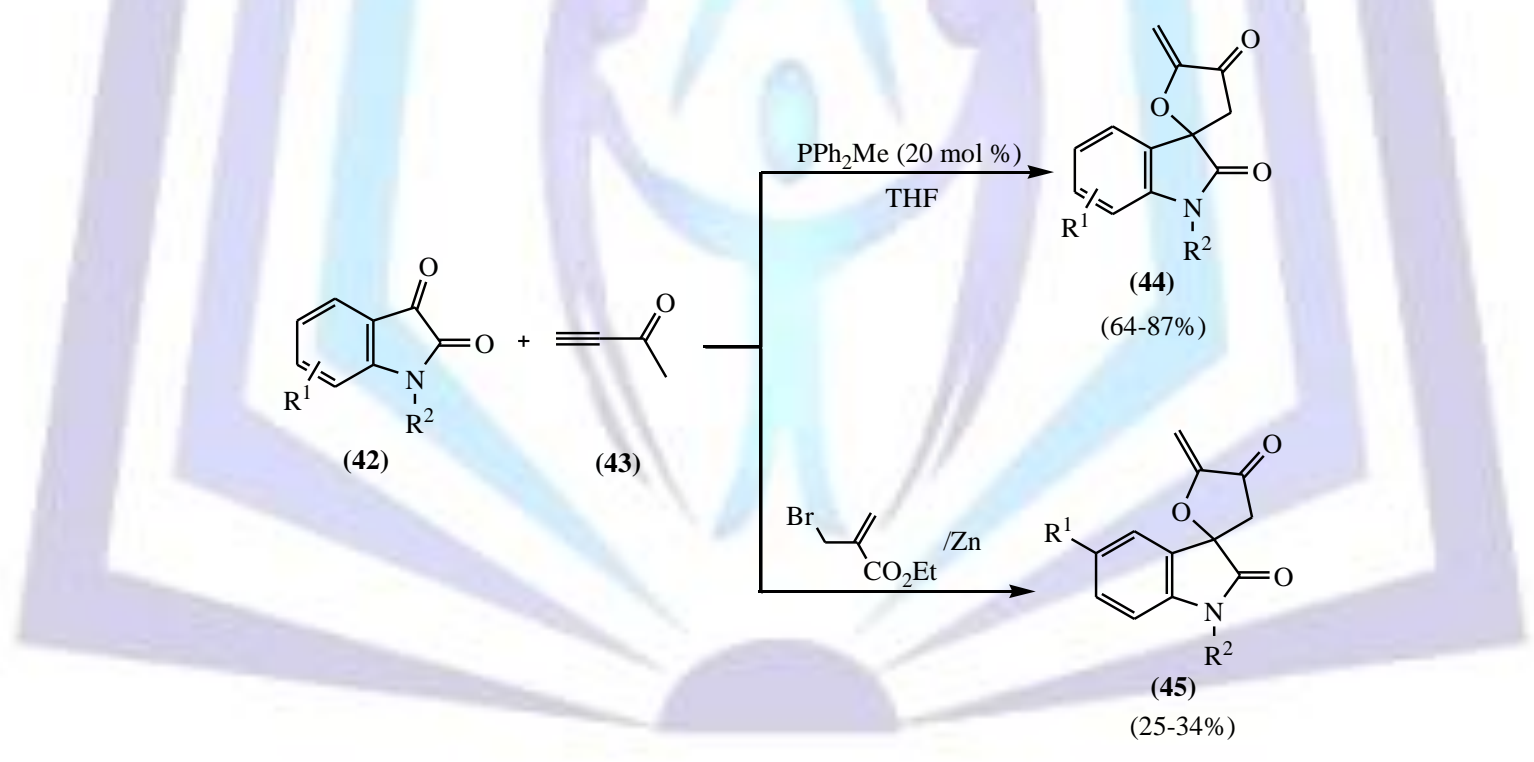

Scheme 12

Sodium 1,2-dihydroxyethane-1,2-disulfonate $\mathbf{4 6}$ was reacted with $\mathrm{N}$-alkyl isatin $\mathbf{4 2}$ in the presence of KCN and yielded 3,4-dihydroxy-5-imino spiro[furan-2,3'-indolin]-2'-one $\mathbf{4 7}{ }^{[127]}$.

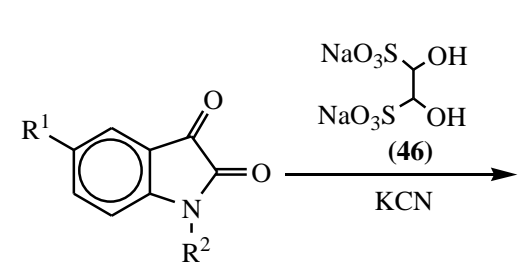

(42)<smiles>[R]c1ccc2c(c1)C1(OC(=N)C(O)=C1O)C(=O)N2[R]</smiles>

(47)

$(37-73 \%)$ 


\section{iii. Spiropyrrolidine oxoindoles}

Spiro[pyrrolidine-2,3-oxindoles] $\mathbf{5 0}$ were synthesized from the reaction of isatin $\mathbf{4 2}$ with aminoacids $\mathbf{4 8}$ and chalcones $49^{[128,129]}$. (Scheme 13)<smiles>[R]CN([R])C(=O)C1C(=O)N([R])c2ccccc21</smiles>

(42)<smiles>[Y][Z1]C1C(c2ccccc2)C2(C(=O)c3ccccc3)c3ccccc3N([R])C(=O)C2(c2ccccc2C[R])N1[R]</smiles>

(50)

\section{Scheme 13}

3-Aryl-4-nitro-5'-phenyl spiro[indoline-3,2'-pyrrolidin]-2-ones $\mathbf{5 3}$ were synthesized as pure region and stereoselective by heating a mixture of 2-nitrovinyl benzene or 1-methoxy-4-(2-nitrovinyl)benzene 51 , isatin and phenyl glycine $52^{[130]}$. (Scheme 14)

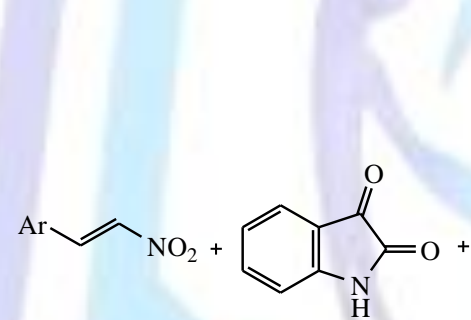

(51)

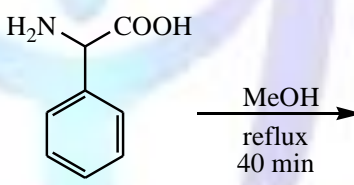

(52)

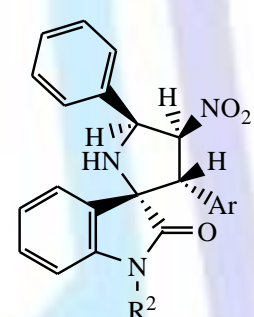

(53)

$(37-73 \%)$

$=4-\mathrm{MeOC}_{6} \mathrm{H}_{4}$

\section{Scheme 14}

Three components condensation of isatin, L-phenyl alanine 54 and 1,4-naphthoquinone 55 afforded 3'-benzyl2,3'-dihydro-1H-spiro[indole-3,1'-naphtho[2,3-c]pyrrole]-2,4',9'-trione ${ }^{56^{[131]}}{ }^{\text {(Scheme 15) }}$<smiles>O=C1Nc2ccccc2C1=O</smiles><smiles>c1ccc(CCc2ccccc2)cc1</smiles>

(54)<smiles>O=C1C=CC(=O)c2cc[cH+]ccc21</smiles>

(55)<smiles>O=C1C2=C(C(=O)c3ccccc31)C1(NC2Cc2ccccc2)C(=O)Nc2ccccc21</smiles>

(56)

\section{Scheme 15}

2-Arylidene---cyclopentanones $\mathbf{5 7}$ and $\mathbf{5 8}$ readily underwent 1,3-dipolar cycloaddition reactions with the nonstabilised ylide generated in situ by the decarboxylative condensation of isatin and sarcosine 48 to afford dispiropyrrolidinyl oxindole derivatives 59 and 60 in a highly regioselective manner (Scheme 16). The reactions were carried out in a microwave oven for a period of $10 \mathrm{~min}$ under neat conditions. The results were compared with those obtained from the conventional method of refluxing with aqueous methanol ${ }^{[132]}$. 


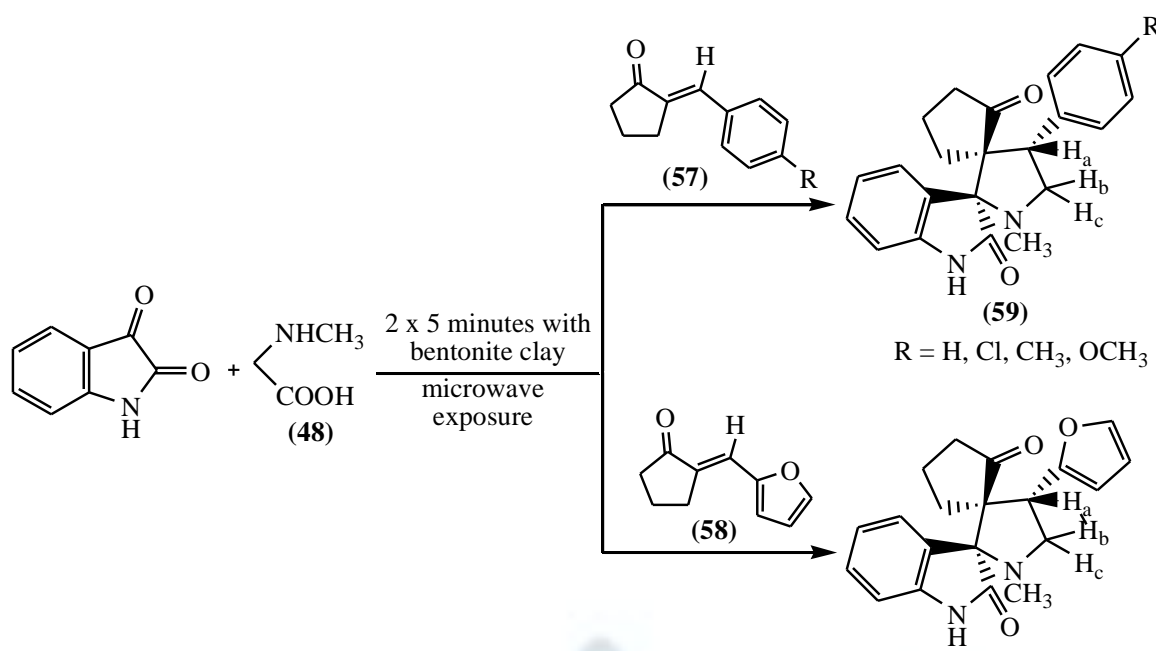

(60)

\section{Scheme 16}

A series of dispiropyrrolidine bisoxindoles 62, 63 were synthesized via a multicomponent 1,3-dipolar cyclo addition reaction ${ }^{[7,13,113,133-142]}$ of isatin, sarcosine 48 and isatylidene malononitrile 61 in refluxing methanol (Scheme 17), also, a series of spiropyrrolidine oxindoles 66 and spiroindan-1,3-diones 67 were synthesized using $2-(1 H$-indole-3carbonyl)-3-phenyl acrylonitrile 64 and 2-(1,3-dioxo-indan-2-ylidene)malononitrile 65 as dipolarophiles, respectively. (Scheme 17,18)<smiles>[R]c1ccc2c(c1)C(=O)C(=O)N2</smiles>

(42)<smiles>CNCC(=O)O</smiles>

$(48)$

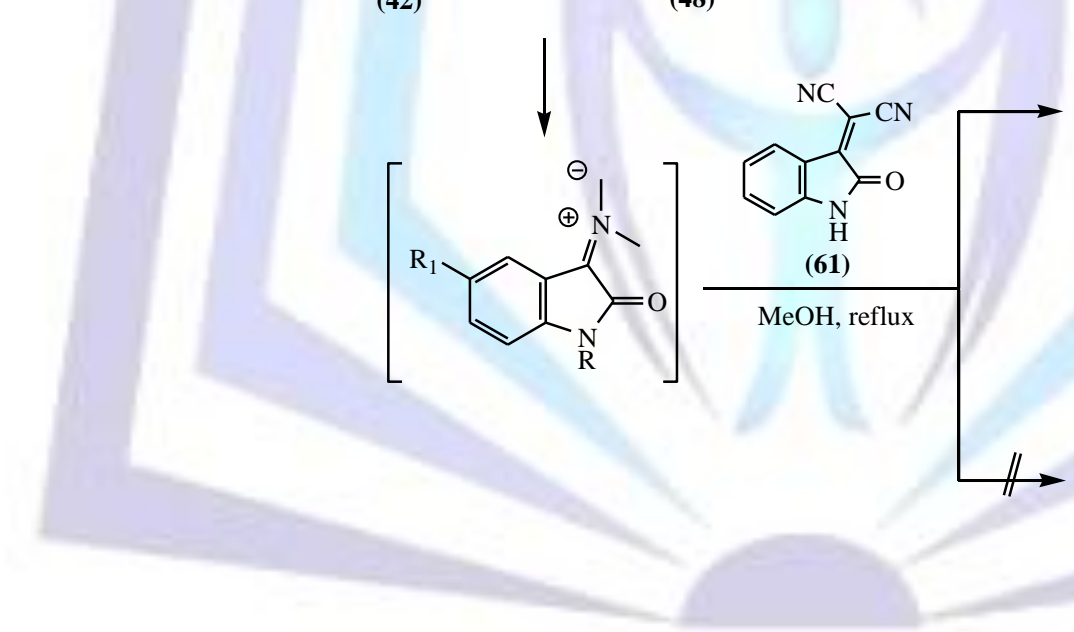

$$
\text { ) }
$$


<smiles>[R]c1ccc([R])c2c(=O)c(=[OH+])n([R])c-2cc1</smiles>

(42)
(48)<smiles>CC(N)C(C#N)=C1C(=O)c2ccccc2C1=O</smiles>

(65) $\mathrm{MeOH}$, reflux<smiles>[R]C1CCCCC1=[N+](C)[O-]</smiles>

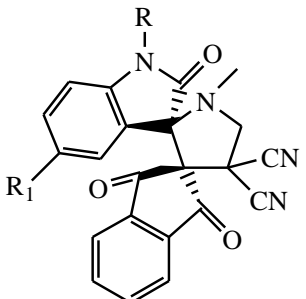

(66)

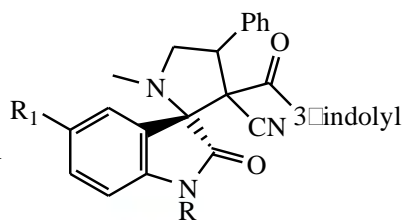

(67)

\section{Scheme 18. Synthesis of spiroindane-1,3-diones 66 and spiropyrrolidine oxindoles 67.}

One-pot three-component domino reactions of cyclic mono ketones, isatin and sarcosine/phenylglycine furnishing highly functionalised dispiropyrrolidines 68-71 in moderate yields are described. The reaction when performed with cyclic amino acid, proline resulted in the dimerization of azomethine ylides. These compounds show high activity against mycobacterium tuberculosis ${ }^{[143]}$. (Scheme 19)

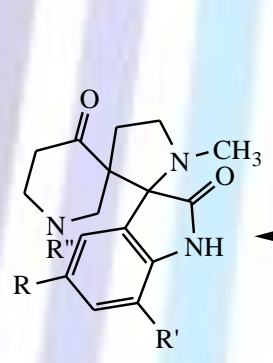

(68)

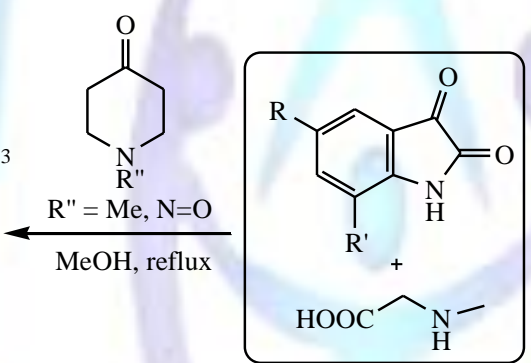

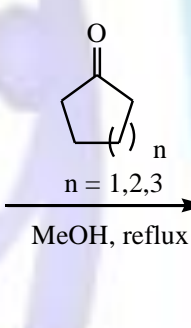
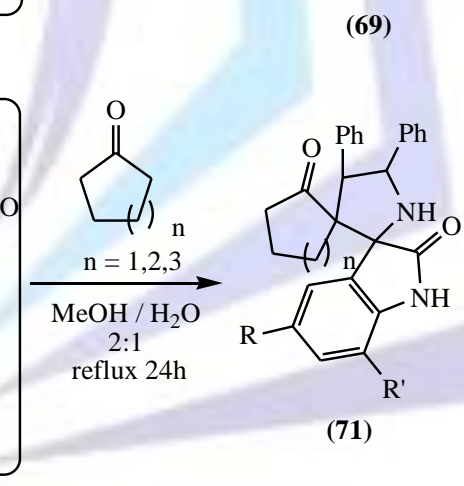

(69)

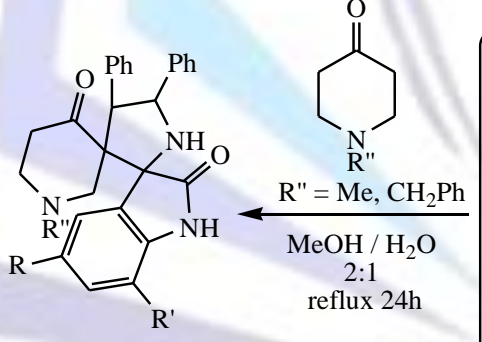

(70)

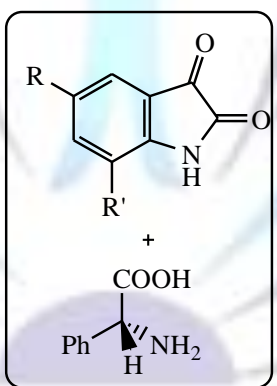

Scheme 19

Similarly, the reaction of isatin, sarcosine and tetralone afforded the desired dispiropyrrolidine $72^{[144]}$.
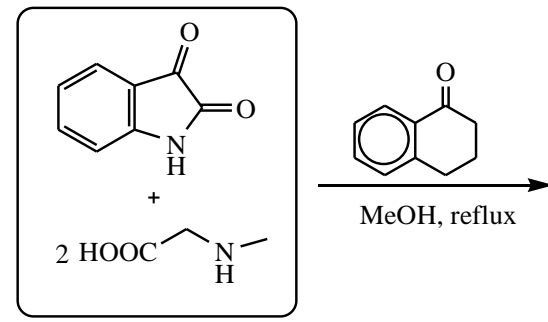

Scheme 20<smiles>CN1CCC2(Cc3ccccc3C2=O)C1</smiles>

(72) 
A facile synthesis of novel spiropyrrolidine, pyrrolizine oxoindoles 73-76 via the one-pot three component condensation of azomethine ylides (generated in situ from sarcosine or proline and aromatic aldehyde) with the Knöevenagel adduct 2-oxo(3H)indole-3-ylidine malonitrile derived from the reaction of 2-oxo-(3H)indole with malononitrile ${ }^{[26,145]}$. (Scheme 21)<smiles>[R]c1ccc([C@H]2N(C)CC(C#N)(C#N)[C@]23C(=O)Nc2ccccc23)cc1</smiles>

(73)

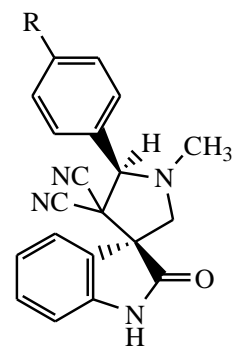

(74)

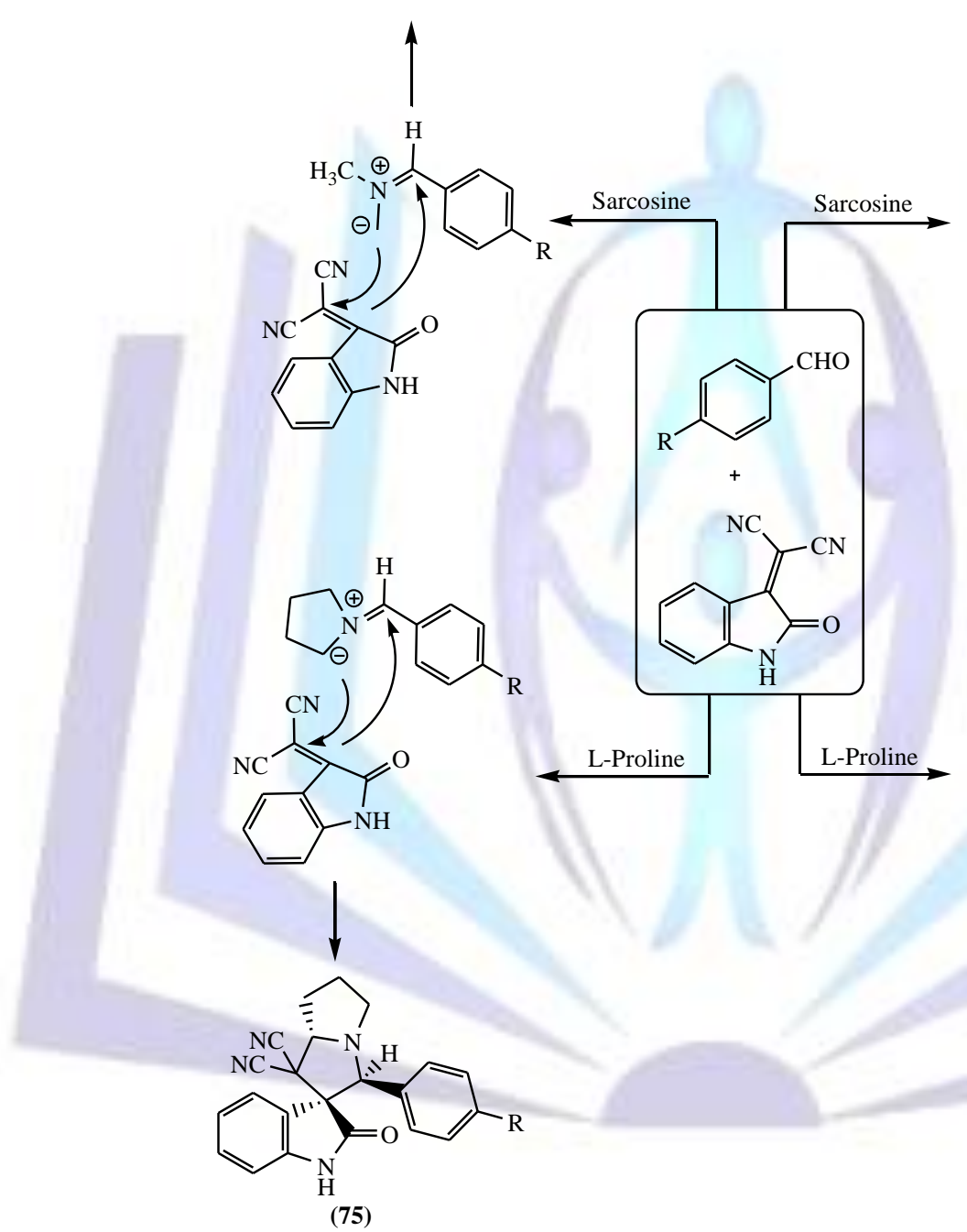

(75)

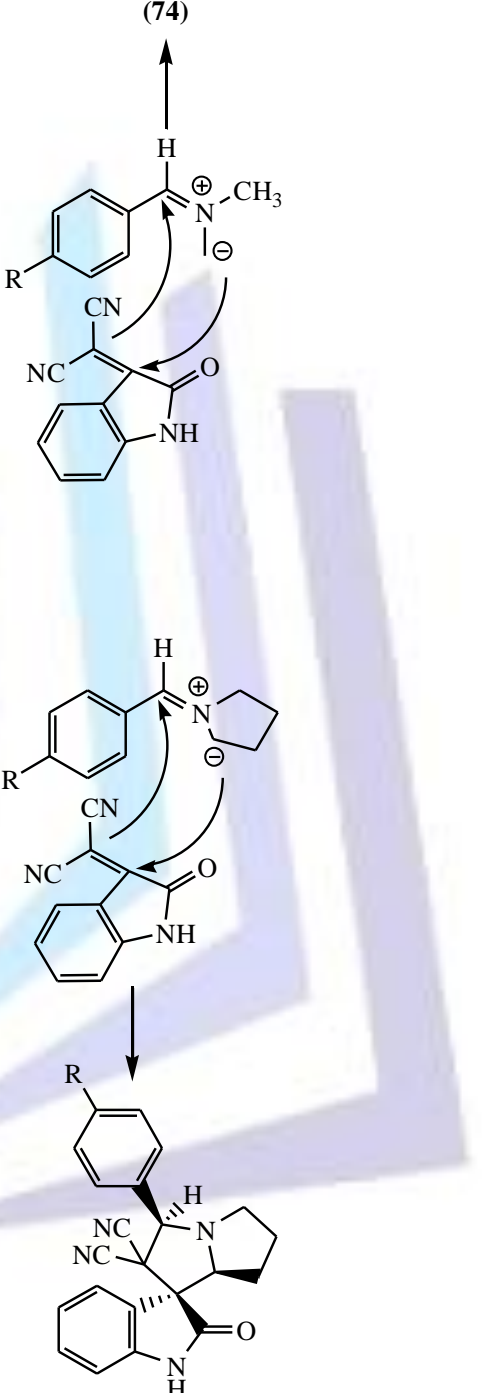

(76)

Scheme 21

Secondary amines react with isatin to give $1: 1$ adduct as a result of nucleophilic attack of the amine at position C-3 ${ }^{\text {[146] }}$.

Pipecolic acid 77 and proline 78 (a cyclic amino acid) when reacted with isatin suffers decarboxylation gave an azomethine ylid $\mathbf{7 9}, \mathbf{8 0}$, which reacts with dipolarophiles such as fumaronitrile $\mathbf{8 1}$ to yield spiro derivatives $\mathbf{8 2}$ [147,148] (Scheme 22) 
<smiles>O=C(O)C1CCCN1C1C(=O)Nc2ccccc21</smiles>

(79)

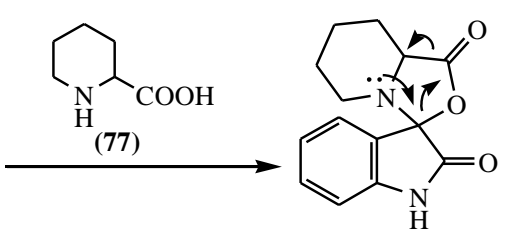

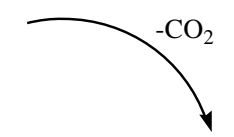<smiles>N#CC1C2CCCCN2C2(C(=O)Nc3ccccc32)C1C#N</smiles>

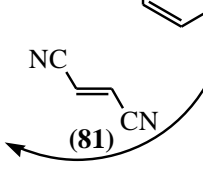<smiles>C1CCNCC1</smiles><smiles>O=C1Nc2ccccc2/C1=N\O</smiles>

(80)

(82)

Scheme 22

Ethyl-2-(2-oxoindolin-3-ylidene)acetate 83 with $N$-methyl- $N$-methylene (phenyl)methanaminium 84 undergo 1,3dipolar cycloaddition and gave the spiropyrrolidine oxoindole derivative $85^{[149]}$. (Scheme 23)<smiles>[R]C=C1C(=O)Nc2ccccc21</smiles>

(83)

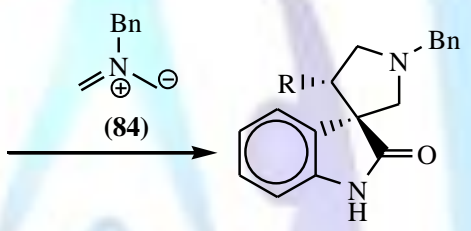

(85)

$\mathrm{R}=\mathrm{NO}_{2}, \mathrm{CO}_{2} \mathrm{Me}$

\section{Scheme 23}

\section{iv. Spiro 1,3-dioxolane and dithiolane oxoindoles}

Spiro[1,3-dioxolane-2,3'-indolin]-2'-ones 87 (cyclic ketals) were obtained using conventional proceduers which consisted in the use of one diol (ethylene glycol for dioxolane group or 1,3-propanediol for dioxane group), isatin 86, $p$ TSA as catalyst in toluene or benzene ${ }^{[150-153]}$. (Scheme 24)

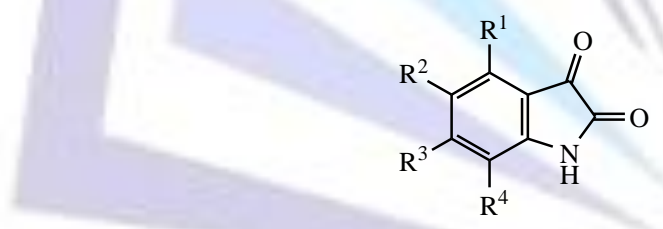

(86)<smiles>[R]c1c([R])c([R])c2c(c1[R])NC(=O)C21OCCO1</smiles>

(87)

\section{Scheme 24}

The dioxolane ketals of isatin and 5-chloroisatin were prepared using an efficient and cleaner procedure than the usual synthetic routes. Keggin heteropolyacids, namely, heteropolyphosphotungstic acid (HPW), $\mathrm{HPW} / \mathrm{SiO}_{2}$ and $\mathrm{Cs}_{2.2} \mathrm{HPW}$, have proven to be useful catalysts, allowing to the fast, selective and solvent-less preparation of ketals, with high yields and $100 \%$ selectivity ${ }^{[154]}$. (Scheme 25)<smiles>CCOC(=O)C1Nc2ccc(I)cc2C1=O</smiles>

(88)<smiles>CC1Nc2ccc(I)cc2C2(OCCO2)C1=O</smiles>

(89)<smiles>O=C1Nc2c(I)cc(I)cc2C12OCCO2</smiles>

(90)

Scheme 25. Synthesis of 90. Reagents and conditions: a) ethylene glycol, $p$-TSA (cat.), toluene, reflux (Dean and Stark conditions) 24 h, $43 \%$; b) ICl, MeOH, reflux, 5 h, 19\%.

The reaction of isatins ${ }^{[155,156]}$ and 1 -alkyl isatins ${ }^{[157]}$ with thiols yield isatin thioketals 91 . (Scheme 26) 


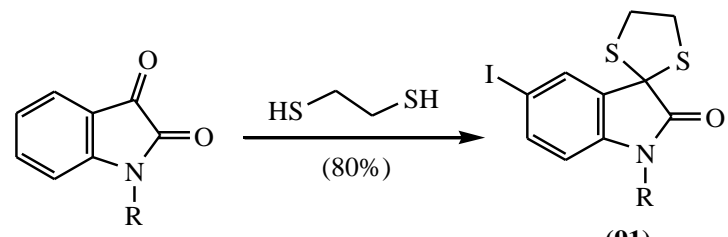

$\mathrm{R}=\mathrm{H}$, alkyl

(91)

\section{Scheme 26}

\section{v. Spirodiazolidene oxoindole}

The reaction of isatin with $N, N$-dimethylethylenediamine in water yields the spirodiazolaneoxindole $92^{[146]}$. (Scheme 27)<smiles>O=C1Nc2ccccc2C1=O</smiles><smiles>CNCCNC</smiles><smiles>CN1CCN(C)C12C(=O)Nc1ccccc12</smiles>

(92)

\section{Scheme 27}

Moreover, the reaction of isatins with o-phenylenediamines 93 was reported to give three products, the proportion between them being affected mostly by the solvent polarity, one of these product identified as spirobenzimidazolines oxoindole derivative $95^{[158]}$. (Scheme 28)<smiles>O=C1Nc2ccccc2C1=O</smiles><smiles>Nc1ccccc1N</smiles>

(93)

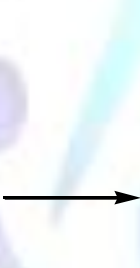<smiles>Nc1ccccc1NC1(O)C(=O)Nc2ccccc21</smiles>

(94)

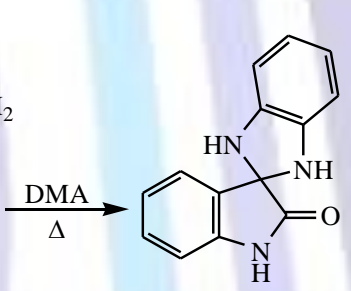

(95)

\section{Scheme 28}

When the reaction is carried out with 1-acylisatin 96, ring opened product 97 was formed using benzene, acetic acid or ethanol as the solvent ${ }^{[159-162]}$. However, it has been reported that with the latter two solvents a spirobenzimidazole derivative 98 is also formed ${ }^{[163]}$. (Scheme 29)

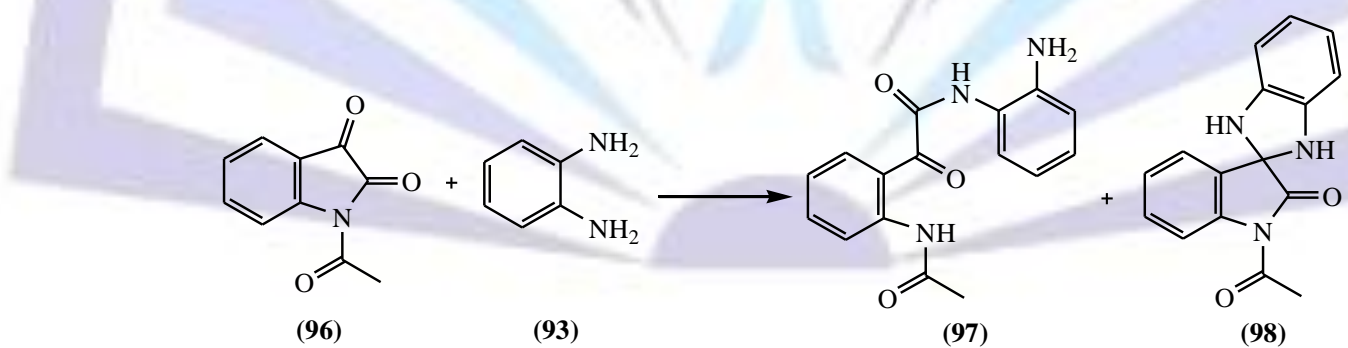

Scheme 29

A simple and facil procedure for the synthesis of pyrazolophthalazinyl spiro oxindoles through one-pot three component reaction of isatin, malononitrile or cyanoacetic ester and phthalhydrazide 99 catalyzed by $\mathrm{NiCl}_{2}$ in $\mathrm{polyethylene}$ glycol (PEG 600) had been described ${ }^{[164]}$.<smiles>[R]c1cc([R])c2c(c1)N([R])C(=[OH+])C2=O</smiles>

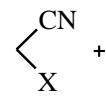<smiles>O=c1[nH][nH]c(=O)c2ccccc12</smiles>

(99)<smiles>[Y]C1=C(N)n2c(=O)c3ccccc3c(=O)n2C12C(=O)N([R])c1cc([R])cc([R])c12</smiles>

(100) 
A possible mechanism for the one-pot reaction to give 100 was described. (Scheme 30)

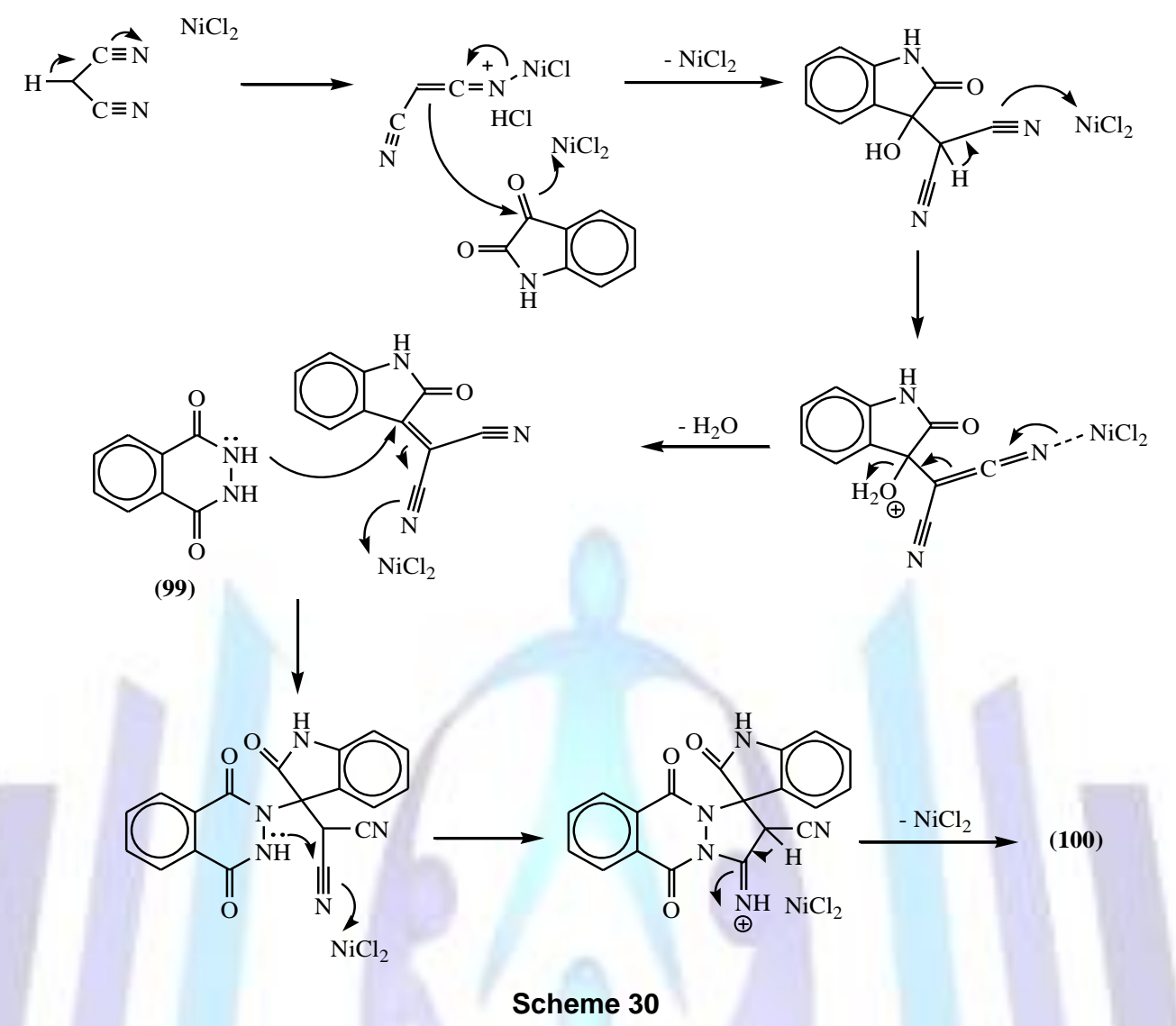

A series of spiro[indoline-3,1'-pyrazolo[1,2-b]phthalazine] derivatives were synthesized via three-component reaction of phthalhydrazide, isatin and malononitrile (cyanoacetic ester) catalyzed by piperidine ${ }^{[165]}$.<smiles>O=c1[nH][nH]c(=O)c2ccccc12</smiles>

(99)<smiles>[X]c1ccc2c(c1)C(=O)C(=O)N2</smiles>

$\mathrm{H}$

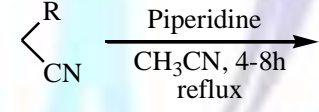
reflux

(

The proposed mechanism for the synthesis of spirooxindole derivatives 101 is described in Scheme 31 . The process represents a typical cascade reaction in which the isatin first condenses with malononitrile to afford isatylidene malononitrile derivative $A$. Then, $A$ is attacked via 1,4-conjugate addition of phthalhydrazide to give the intermediate $B$ followed by cyclization affords the corresponding product 101.

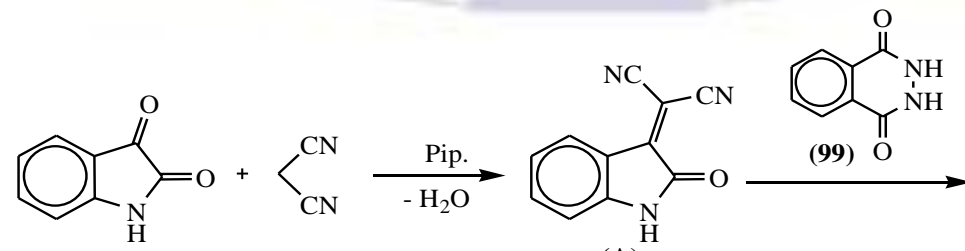

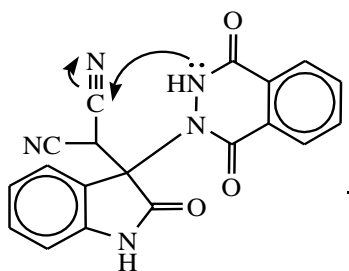

(B)<smiles>[R]C1=C(N)n2c(=O)c3ccccc3c(=O)n2C12C(=O)Nc1cc([X])ccc12</smiles>

(101)<smiles>C=C=CN1C(=N)C(C)C1(C(=N)N)n1c(=O)c2ccccc2c(=O)n1C</smiles>

(C)

Scheme 31 


\section{vi. Spirooxazole oxoindoles}

Two equivalent of isatin reacted with one equivalent of ammonia to afford the intermediate 102 which suffers lactonization to give the spiro compounds $103^{[166]}$. (Scheme 32 )

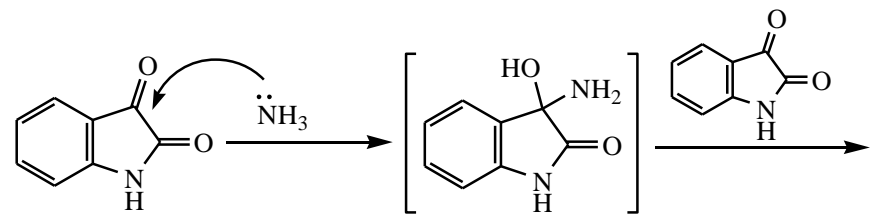<smiles>O=C1Nc2ccccc2C1=NC1(O)C(=O)Nc2ccccc21</smiles>

(102)<smiles>CC(C)C</smiles>

(103)

\section{Scheme 32}

The reaction of isatin with $N, N$-dimethylethylenediamine when performed by azeotropic distillation in toluene yielded the unusual 2:1 adduct $\mathbf{1 0 5}$ as the result of the addition of an unstable azomethine ylide 104 to isatin [146] (Scheme 33)<smiles>O=C1Nc2ccccc2C1=O</smiles><smiles>CNCC(C)NC</smiles><smiles>CN1CCN(C)C(O)(c2ccccc2N)C1=O</smiles><smiles>C=C</smiles>

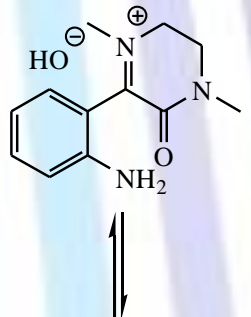

$\Theta$<smiles>CC1=C(c2ccccc2N)N(C)CCN1C</smiles>
(104)

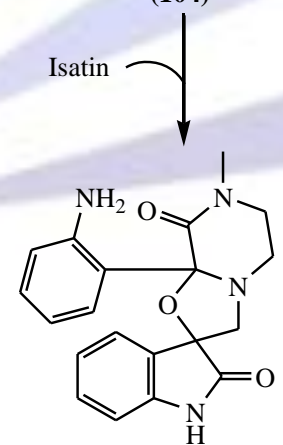

(105)

\section{Scheme 33}

\section{vii. Spiroisoxazolidine oxoindoles}

Spiro-[indoline-isoxazolidines] were synthesized by the cycloaddition reaction between ethyl (3-indolylidene)acetate $1^{[167]}$ and various substituted $\alpha, N$-diphenylnitrones 106 (Scheme 34). The nitrones ${ }^{[168-171]}$ were prepared by the condensation of appropriately substituted aromatic aldehydes with phenylhydroxylamine in ethanol at room temperature. Though, spiro compounds 107 and 108 have been prepared just by irradiating the mixture of ethyl(3-indolylidene)acetate 1 and the $\alpha, N$-diphenylnitrones 106 in the absence of any solvent for 4-5 $\min ^{[172]}$. 


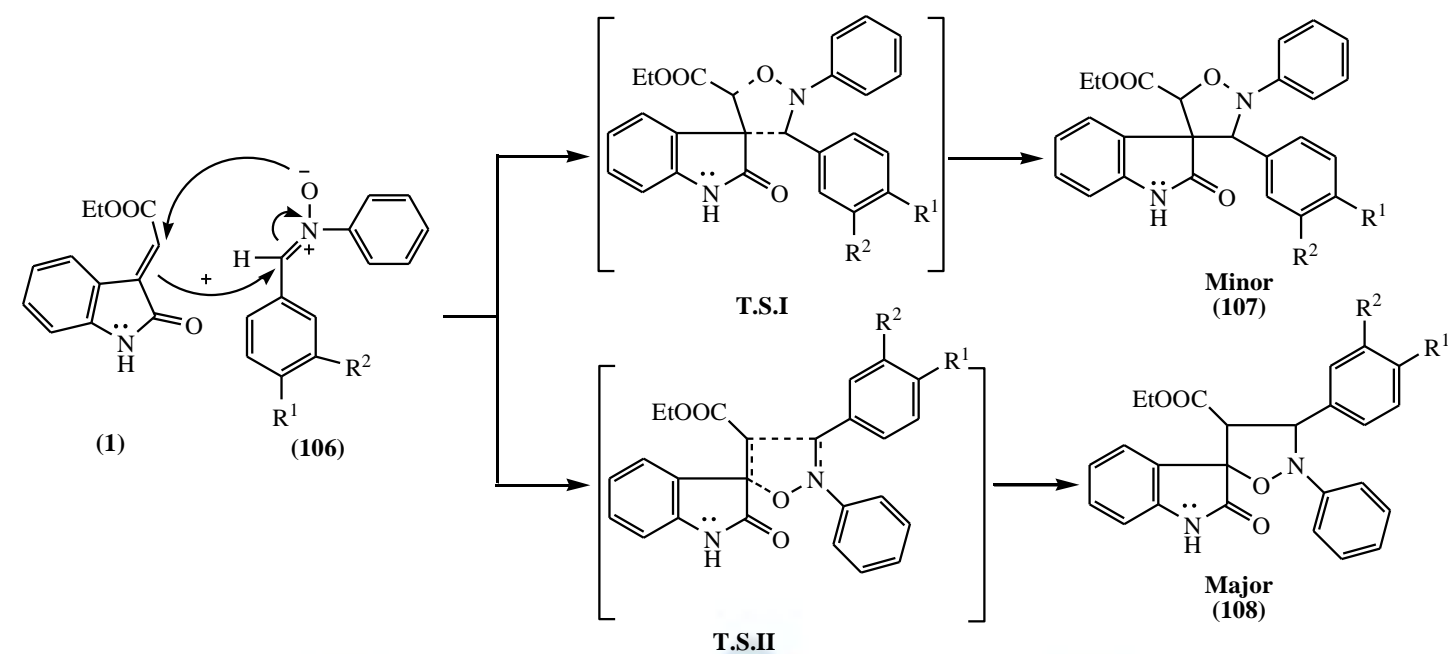

\section{Scheme 34}

The spiro[indole-pyrazoles] 113, spiro[indole-isoxazoles] 114 were synthesized through conventional, microwave solution phase and microwave solid phase reactions of 3-aroyl methylene-indole-2-ones 112 with hydrazine hydrate and hydroxyl amine hydrochloride ${ }^{[173]}$. (Scheme 35)

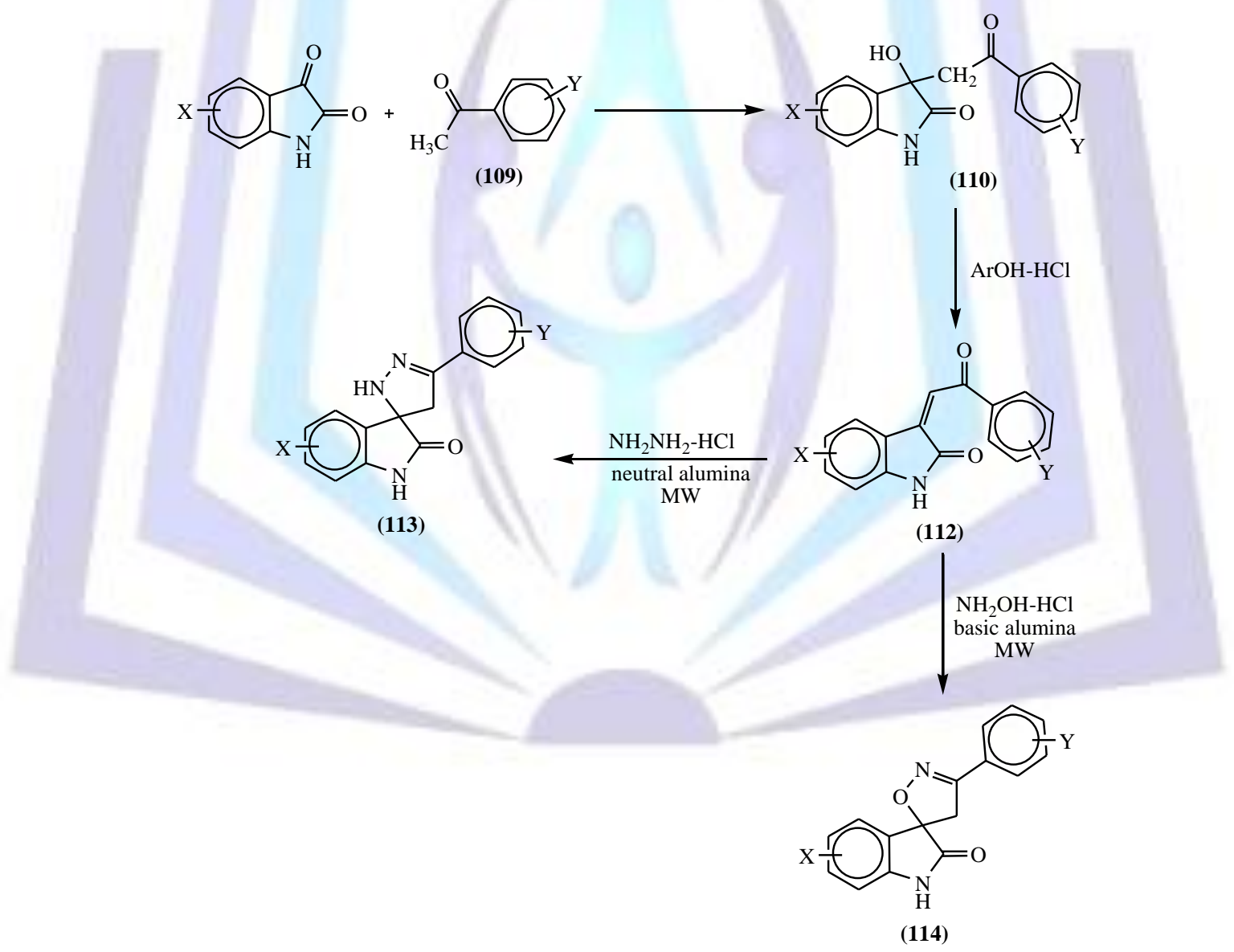

Scheme 35

1-Alkyl (or Aryl)-3-(2-oxopropylidene)indolin-2-one 4 reacted with hydrazine hydrate, phenyl hydrazine, phenyl thiourea and/or hydroxyl amine hydrochloride gave spiropyrazole- and spiroisoxazole oxoindoles $115^{[174-176]}$. 


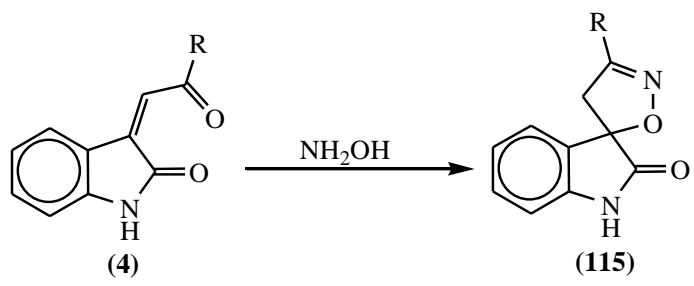

$(35-66 \%)$

\section{viii. Spirothiazolidine oxoindoles}

Isatin-3- $N$-arylamines 116 react with mercaptoacetic acid to yield spirothiazolidinones $117{ }^{[177]}$ which can be further acylated or submitted to a Mannich reaction giving substitution product at the oxoindole nitrogen atom 118 [178] (Scheme 36)

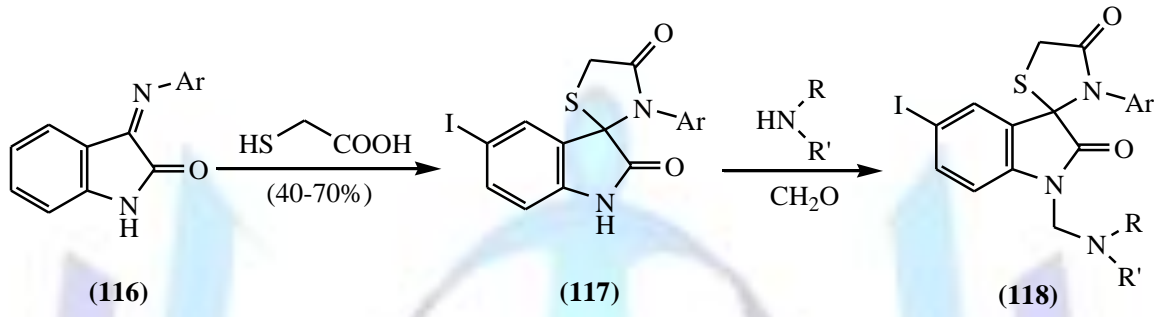

\section{Scheme 36}

The synthesis of 3 '-[(4-substituted phenyl-1- $N$-ethoxyphthalimido-6'-pyridin-2-yl]-3,3a'-dihydro-6' $H$-spiro[indole3,5'-[1,3]-thiazolo[4,5-c]isoxazol]-2(1H)-ones 124 is carried out through a five step pathway starting from acid catalyzed condensation of 2-aminopyridine with isatin yielding 3-(pyridine-2-ylimino)-1,3-dihydro-2H-indol-2-one 119 which on reaction with thioacetic acid in the presence of anhydrous $\mathrm{ZnCl}_{2}$ give 3 '-pyridin-2-yl-4' $\mathrm{H}$-spiro[indole-3,2'-[1,3]thiazolidine]$2,4^{\prime}(1 H)$-dione 120 . Reaction of 120 with various araldehydes 121 affords the corresponding 5-[(4-[indole-3,2' $[1,3]$ thiazolidine]-2,4' $(1 H)$-diones 122 . These chalcones are further cyclized with hydroxylamine hydrochloride to furnish $3^{\prime}$ (4-substituted phenyl)-6'-pyridin-2-yl-3,3a'-dihydro-6' $H$-spiro[indole-3,5'-[1,3]thiazolo [4,5-c]isoxazol]-2 $(1 H)$-ones 123 which are subsequently condensed with $\omega$-bromoethoxyphthalimide to yield the targeted compounds $124^{[17 \%]}$. (Scheme 37 ) 


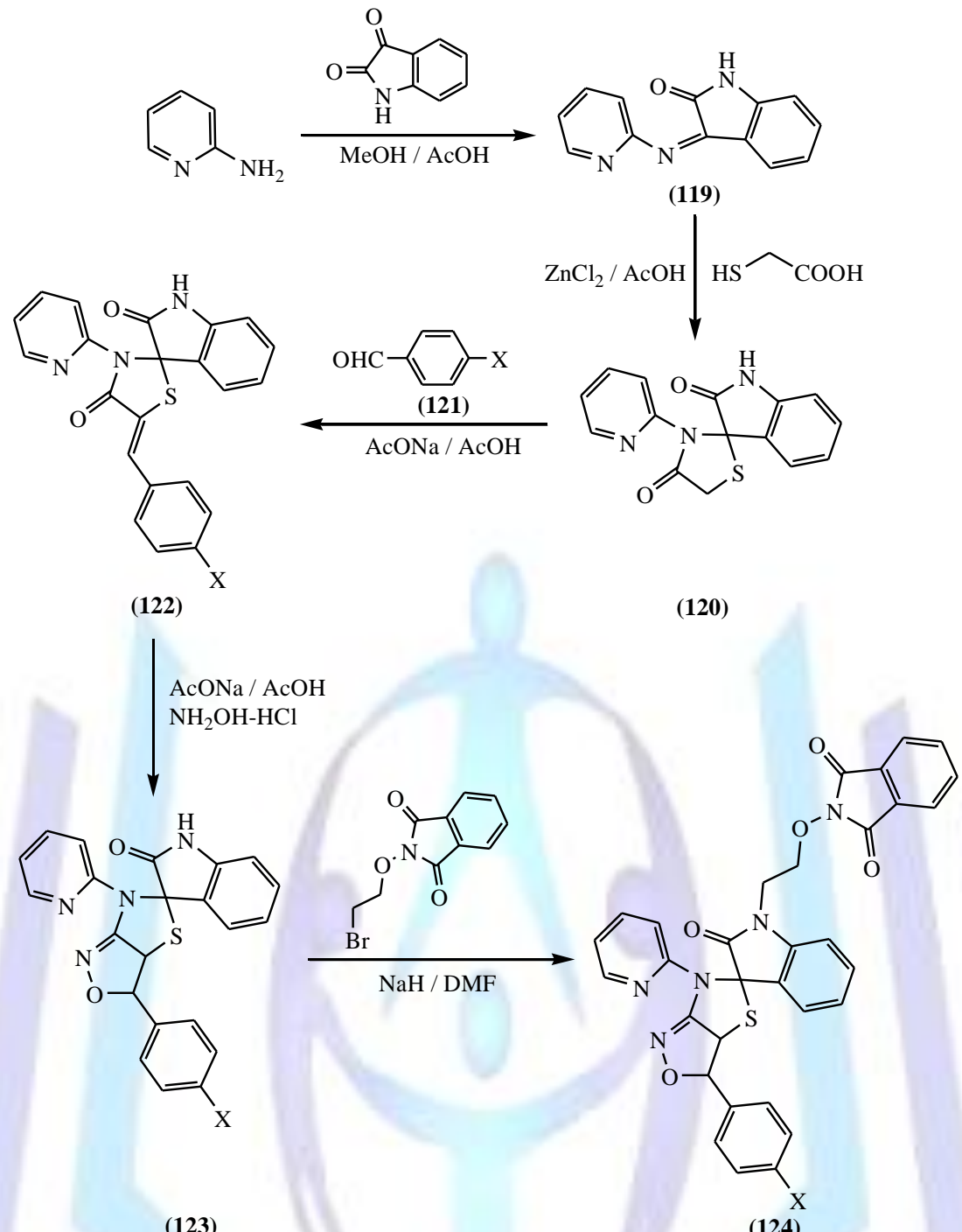

Scheme 37

2-[2,4'-dioxospiroindole-3,2'-thiazolidin-3'-yl]alkanoic acids 127 have been prepared by reacting 2-indolone-3-yl imino alkanoic acid 126 with mercapto acetic acid ${ }^{[180]}$. (Scheme 38)
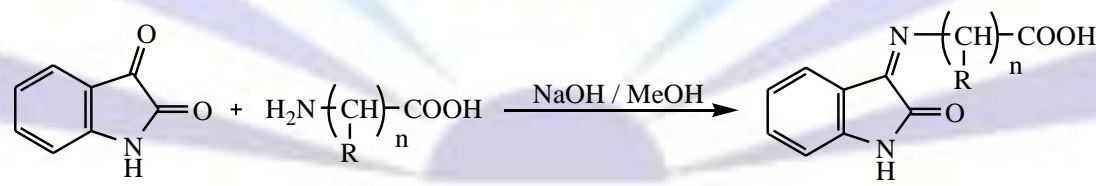

(125)

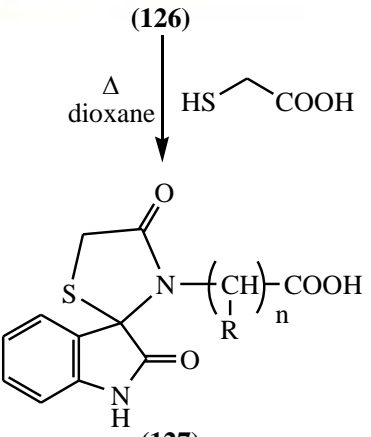

Scheme 38 
The hydrazide 128 condensed with isatin to give the desired condensation product 129 which when treated with thioglycolic acid afforded 2,4-(dioxospiro [indoline-3,2-thiazolidine]-3'-yl)-2-methyl-1,8-naphthylidine-3-carboxamide 130 ${ }^{[181]}$. (Scheme 39)<smiles>O=C1Nc2ccccc2C1=[OH+]</smiles><smiles>Cc1nc2ncccc2cc1NN</smiles>

(128)<smiles>Cc1nc2ncccc2cc1C(=O)N/N=C1\C(=O)Nc2ccccc21</smiles>

(129)<smiles>Cc1nc2ncccc2cc1C(=O)NN1C(=O)CSC12C(=O)Nc1ccccc12</smiles>

Scheme 39

1-Methyl isatin reacts with 2 -mercaptoaniline only at reflux furnishing solely the spiro[indole-3,2' $[1,3]$ benzothiazole-2(1H)one $131^{[182]}$. (Scheme 40)<smiles>CN1C(=O)C(=O)c2ccccc21</smiles><smiles>Nc1ccccc1S</smiles><smiles>CN1C(=O)C2(Nc3ccccc3S2)c2ccccc21</smiles>

(131)

\section{Scheme 40}

\section{ix. Spiro 1,3-oxathiolane oxoindoles}

Spiro[indoline-3,2'-[1,3]-oxathiolane]2,5'-dione 132 was synthesized by the reaction of isatin with mercaptoacetic acid in the presence of $P$-toluene sulphonic acid ${ }^{[183]}$.

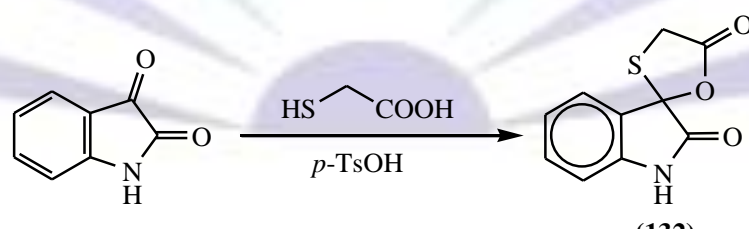

(132)

\section{x. Spirotriazole oxoindoles}

The indole ring, linked to other heterocyclic system through the spiro carbon atom at C-3, are of interest. In addition, varied pharmacological properties are associated with 1,2,4-triazolines ${ }^{[184-189]}$. Spiro-[3H-indole-3,3'-[ $\left.\Delta^{2}-1-2-4\right]-$ triazoline]-2-ones 135 were obtained by the reaction of isatin imines $116^{[190]}$ with $\mathrm{C}$-acetyl nitrile imine 134 , generated in situ from the corresponding hydrazinoyl bromide 133. (Scheme 41) 
<smiles>[X]c1ccc(/N=C2\C(=O)Nc3ccccc32)cc1</smiles>

(116)<smiles>CC(=O)/C(Br)=N/Nc1ccc(C)cc1</smiles>

(133)

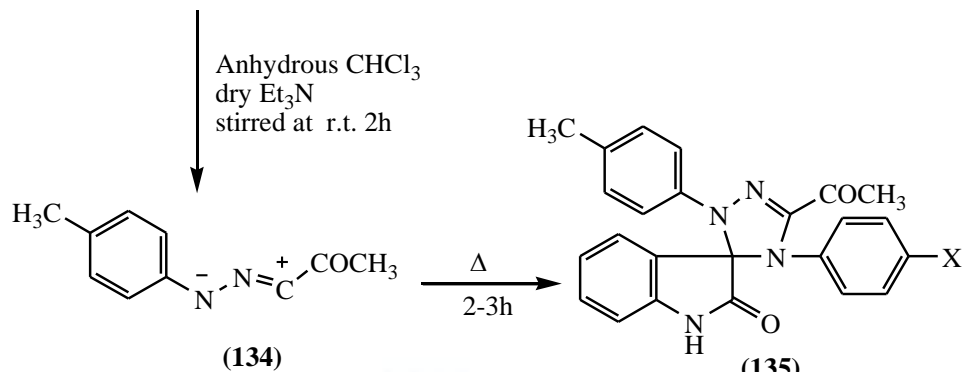

Scheme 41

1-Alkyl-3'-aryl-3',5'-dihydrospiro[indoline-3,4'-[1,2,3]triazol]-2-one 136 was prepared via the condensation of $N$ alkyl isatine with aromatic amine followed by diazomethane ${ }^{\text {|191,192]. }}$.

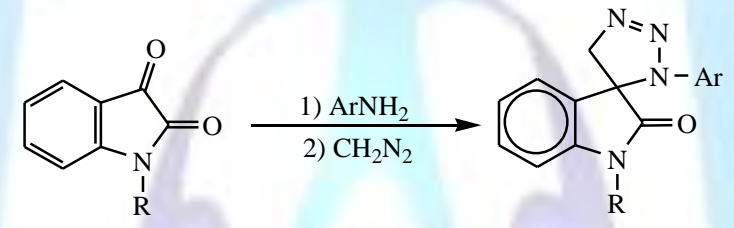

(136)

\section{xi. Spiro[1,3,4]thiadiazole oxoindoles}

Spiro[indoline-3,2'-[1,3,4]thiadiazole 137 was obtained upon treatment of isatin with thiobenzoyl hydrazine ${ }^{[193,194]}$.

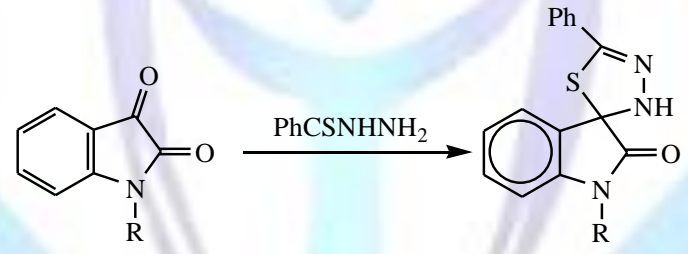

(137)

$\mathrm{N}$-Substituted isatin when reacted with thioxodihydrazide in acetic acid with $\mathrm{HCl}$ afforded the spiro[1,3,4]thiadiazole oxoindole derivative 138

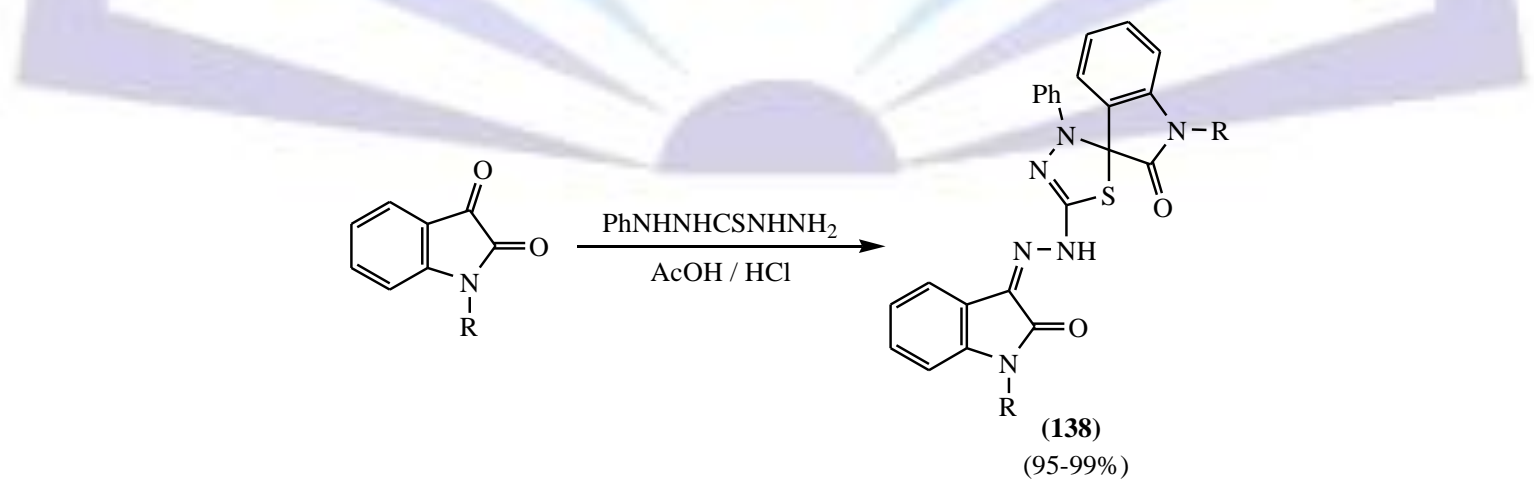

Isatin thiosemicarbazone was reacted with freshely distilled acetic anhydride yielded $N$-(1,3'-diacetyl-2-oxo-3' $H$ spiro[indoline-3,2'-[1,3,4]thiazole]-5'-yl] acetamide $139^{[196]}$. 


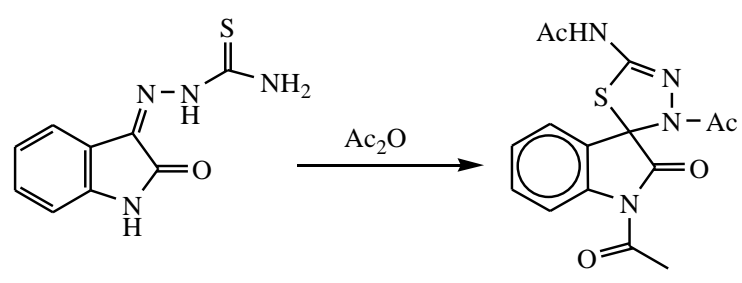

(139)

\section{xii. Spiro[1,3,4]oxadiazole oxoindoles}

5-spiro(isatin)2( $N$-acetyl hydrazine)-4-( $N$-acetyl)- $\Delta^{2}-1,3,4$-oxadiazoline 140 was formed by oxidative cyclization of isatin-3-carbohydrazone with freshly distilled acetic anhydride ${ }^{[197]}$.

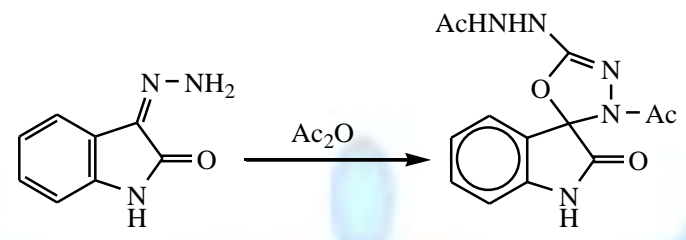

(140)

\section{D) SPIRO[SIX-MEMBERED RING]OXOINDOLES}

\section{i. Spiro cyclohexane-1,3'-indoline}

A new synthetic pathway to spiro[cyclohexane-1,3'-indoline]-2',4-diones 146, 147 was found starting from 3chloromethylene-2-indolones 141 and Danishefsky's diene 142. Their synthesis consist of several steps involving the formation of the cycloadducts, the 6-chloro-4-trimethylsilyloxy-2-methoxyspiro[cyclohex-3-en-1,3'-indolin]-2'-one 143 derivatives, transformed into spiro[cyclohexa-2,5-dien-1,3'-indoline]-2',4-diones 145 via 6-chloro-spiro[cyclohex-2-en-1,3'indoline]-2',4-dione 144 intermediates. The reduction of spiro[cyclohexa-2,5-dien-1,3'-indoline]-2',4-diones 145 gave spiro[cyclohexane-1,3'-indoline]-2',4-diones 146,147. ${ }^{[198]}$ (Scheme 42)

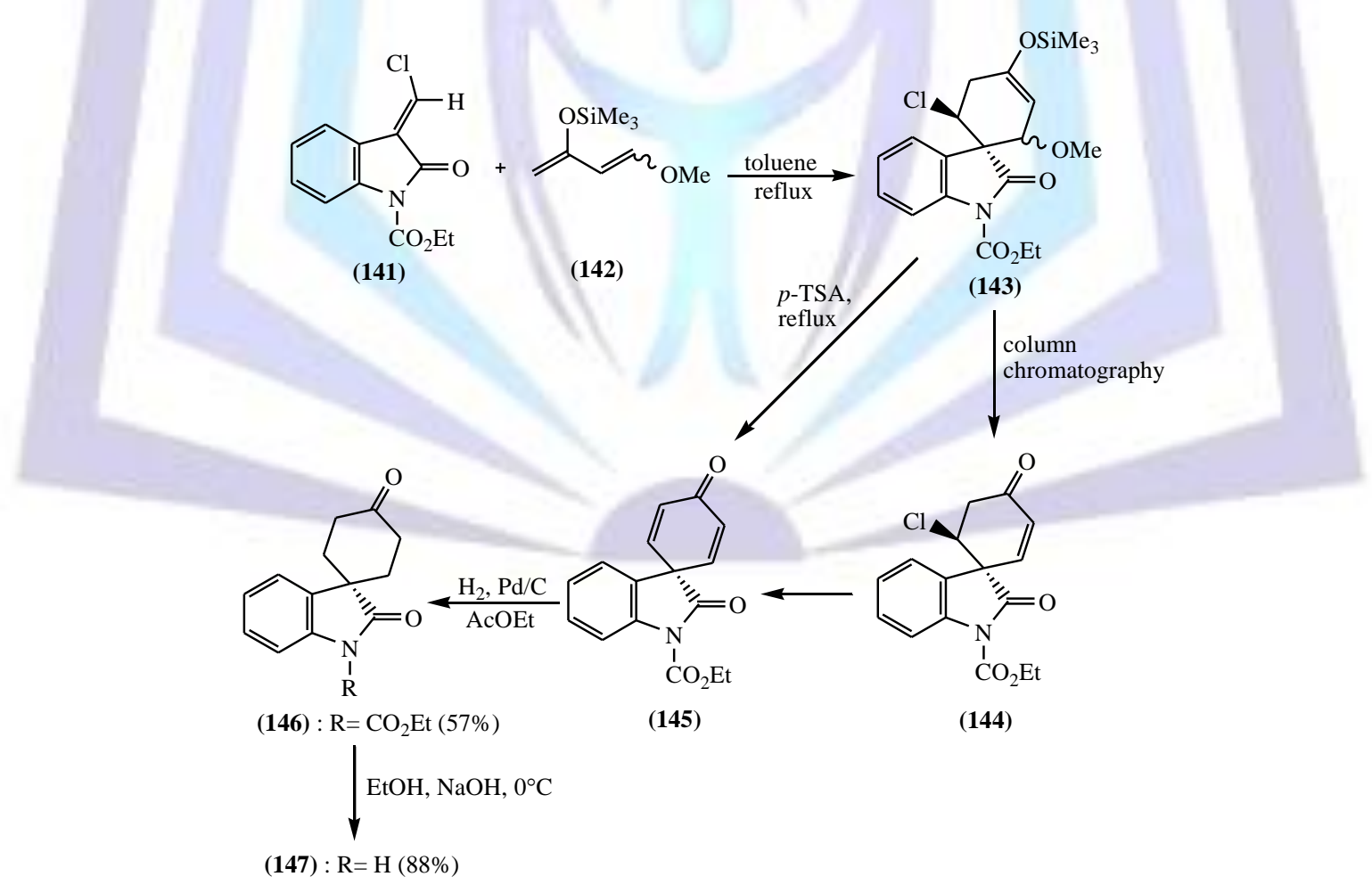

\section{Scheme 42}

The reaction of isatin and acetic anhydride in the presence of pyridine afforded the spiro cyclohexane oxoindole 149 together with other polycyclic product 148 


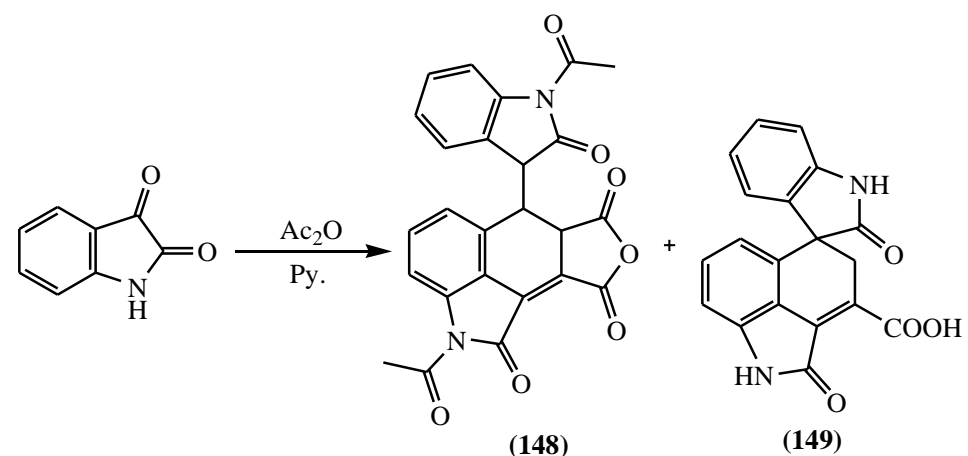

Ethyl 2-(2-oxoindolin-3-ylidene)acetate 1 was reacted with cisoid diene in anhydrous aluminium chloride to give the spiro cyclohexene oxoindole derivative $150^{[201]}$.

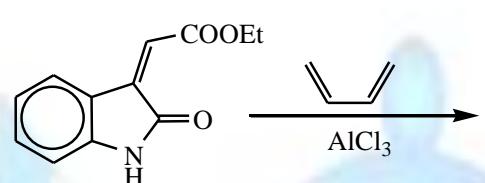

(1)<smiles>CCOC(=O)C1CC=CCC12C(=O)Nc1ccccc12</smiles>

\section{ii. Spiro pyridine oxoindole}

The synthesis of spirooxy indole system based on the condensation of isatins with dimedone ${ }^{\text {[202] }}$ and substituted 6 -aminouracils ${ }^{[203]}$ resulting in spiro[indoline-3,9'-xantene]trione and spiro[pyrimido[4,5- $b$ ]quinolone 5,5'-pyrrole[2,3d]pyrimidine] pentone derivatives, respectively, have been described 202,203$]$. The synthesis of 1,7-dihydro spiro[pyrazolo[3,4-b]pyridine-4,3'-indole]-2',6(1'H,5H)diones based on a three-component condensation of 5aminopyrazole derivatives 154, isatin and Meldrum's acid ${ }^{[204]}$. (Scheme 43)<smiles>[R]n1ncc(C(=O)OCC)c1N</smiles>

(151)<smiles>[R]n1ncc(C(=O)O[Na])c1N</smiles>

(152)

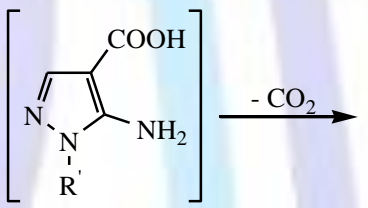

(153)<smiles>[R]n1nccc1CC</smiles>

(154)<smiles>[R]N1C(=O)C(=O)c2ccccc21</smiles>

R"<smiles>[R]N1C(=O)C2(CC(=O)Nc3c2cnn3[R])c2ccccc21</smiles>

(155)

\section{Scheme 43}

It was assumed that the reaction occurs according to one of two most probable paths (Scheme 44). Thus, isatin can first add to 5-aminopyrazole 154 giving the adduct 156, which further reacts with Meldrum's acid to form unstable intermediate 157, which eliminates $\mathrm{CO}_{2}$ and acetone (path A) affording the final product 155. An alternative scheme of the process includes the Michael addition of 5-aminopyrazole 154 to oxoindolylidene derivative of Meldrum's acid 158 followed by the intermolecular cyclization (path B). 

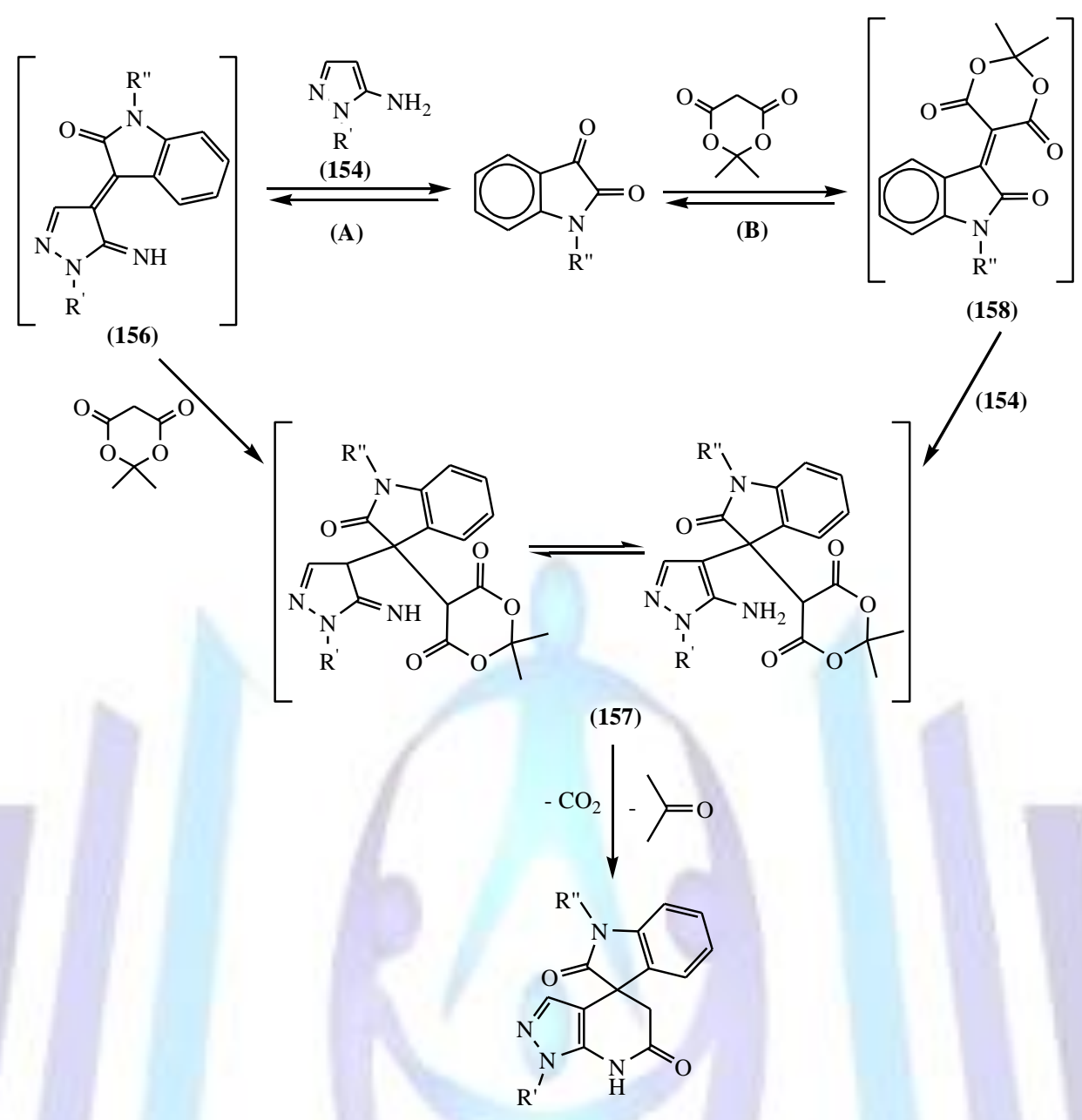

(155)

\section{Scheme 44}

A one-pot, pseudo four-component, and simple synthesis of spiro[diindenopyridine-indoline]triones 160 via the reaction of 1,3 -indandione $\mathbf{1 5 9}$, aromatic amines and isatins using a 'Grindstone Chemistry' method is reported [75] (Scheme 45,46)

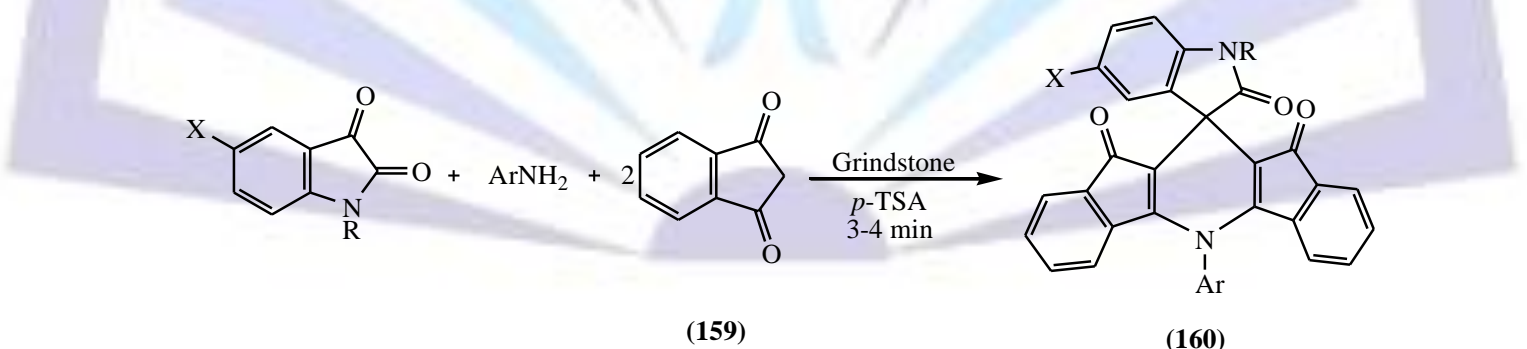

Scheme 45. One-pot synthesis of spirodiindenopyridine-indolines 160. 
<smiles>[X]c1ccc2c(c1)C(=O)C(=O)N2[R]</smiles><smiles>[X]c1ccc2c(c1)C(C1C(=O)c3ccccc3C1=O)(C1C(=O)c3ccccc3C1=O)C(=O)N2</smiles>

(162)<smiles>[X]c1ccc2c(c1)C(C1C(=[NH2+])c3ccccc3C1=O)(C1C(=O)c3ccccc3C1=O)C(=O)N2</smiles>

(163)<smiles>[X]c1ccc2c(c1)C1(C(=O)N2)C(=O)c2ccccc2N([Al])C2=C1C(=O)c1ccccc12</smiles>

(160)

Scheme 46. Proposed mechanism for the synthesis of spirodiindenopyridine-indoles 160.

The synthesis of spiro[benzo[h]pyrazolo[3,4-b][1,6] naphthyridine-7,3'-indoline]-2',6(5H)diones 166 and spiro [chromeno[4,3-b]pyrazolo[4,3-e]pyridine-7,3'-indoline]-2',6 $(6 \mathrm{a} H, 10 H)$ diones 168 via a one-pot, three-component reaction of 4-hydroxy-1-methyl quinolin-2(1H)-one 164, or 4-hydroxy coumarin 167, isatin and $1 H$-pyrazol-5-amines in water was reported $^{[205]}$. (Scheme 47,48)<smiles>C=C(/C=C(/O)c1ccccc1N)N(C)C</smiles>

(164)<smiles></smiles>

(165)

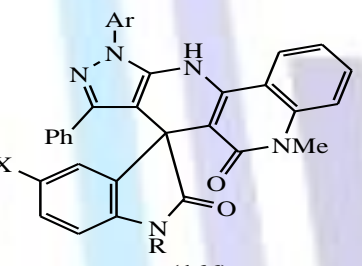

(166)

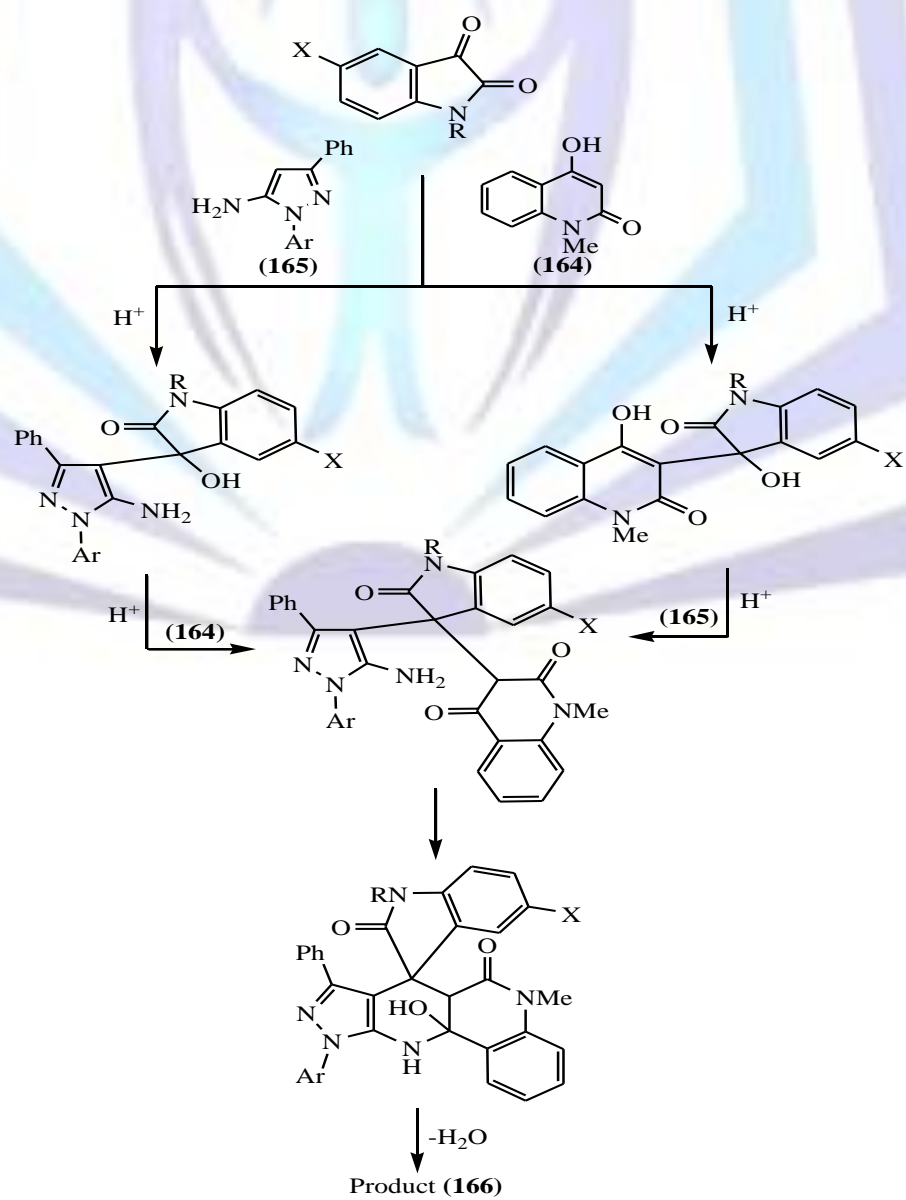

Scheme 47 
<smiles>[X]c1ccc2c(c1)C(=O)C(=[OH+])N2[R]</smiles>

(167)

(165)

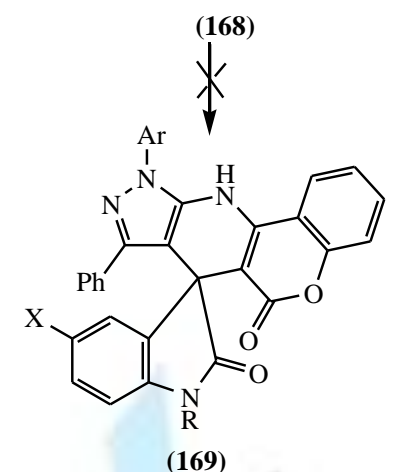

(169)

\section{Scheme 48}

The synthesis of spiro[indoline-3,4'-pyrazolo[3,4-b]pyridine]-2,6'(1'H)-diones $\mathbf{1 7 0}$ by the reaction of 4hydroxycoumarin, isatins and $1 \mathrm{H}$-pyrazol-5-amines in water under ultrasonic irradiation is reported. The advantages of this method are the use of an inexpensive and readily available catalyst, easy work-up, good yields, and the use of water as a solvent that is considered to be relatively environmentally benign ${ }^{[206]}$. (Scheme 49)
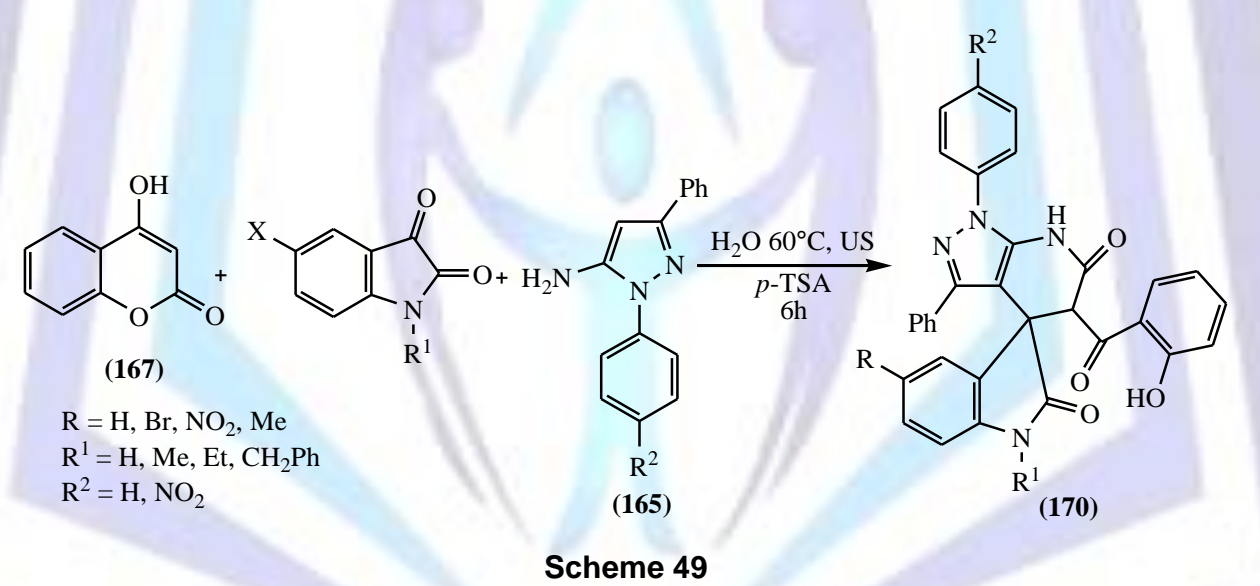

Exact mechanism for the formation of spiro[indoline-3,4'-pyrazolo[3,4-b]pyridine]-2,6'(1'H)-diones 170 , however, two reasonable possibilities are indicated in (Scheme 50). Addition of 4-hydroxycumarin to isatin leads to highly reactive intermediate A via standard nucleophilic addition. Interception of A by $1 \mathrm{H}$-pyrazol-5-amines 165 and followed by cyclization produces the corresponding spirooxindole 170 (Pathway A). Isatin and $1 \mathrm{H}$-pyrazol-5-amines 165 would react to produce highly reactive intermediate $\mathbf{B}$, followed by a nucleophilic addition with 4-hydroxycoumarin and cyclization to afford spirooxindole 170 (Pathway B) . (Scheme 50) 


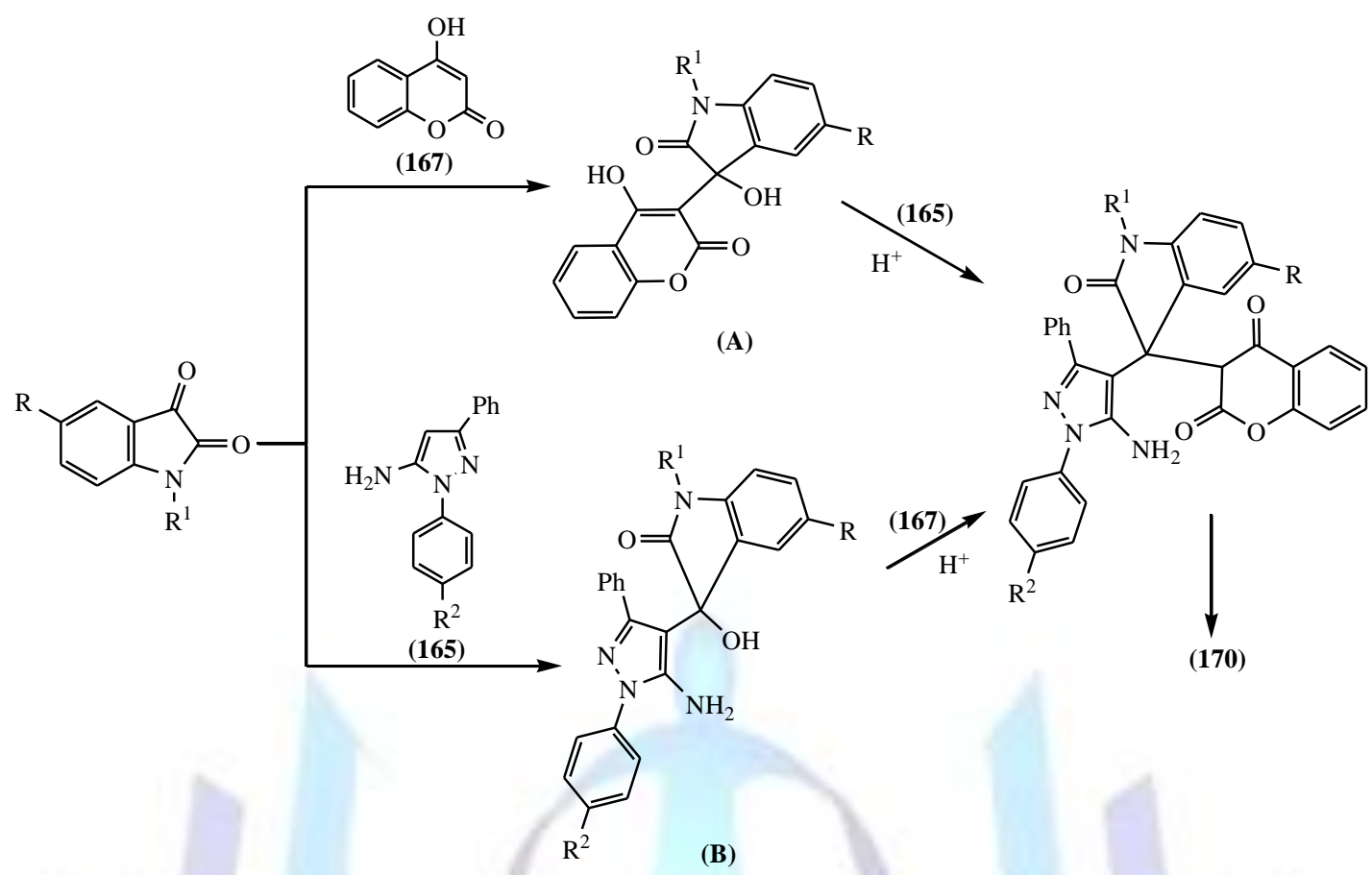

Scheme 50

2'-Hydroxy-6'-mercapto-2-oxo-1H-spiro[indolin-3,4'-pyridine]3,5-dicarbonitrile 171 was prepared from the reaction of isatin with malononitrile followed by cyanothioacetamide in presence of piperidine in refluxing ethanol ${ }^{[207]}$.

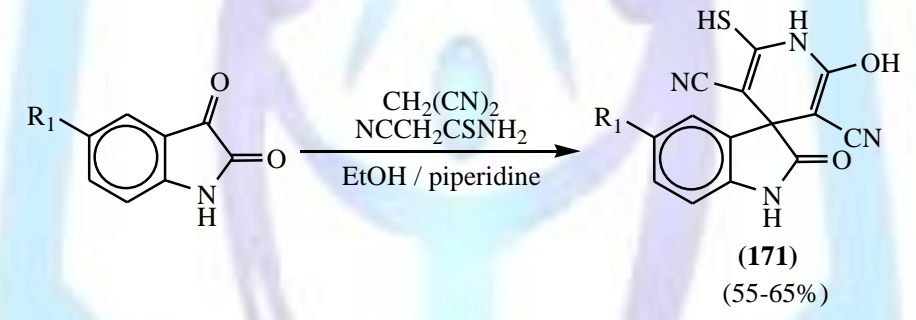

2-Oxoindol-3-ylidene malononitrile $172\left(\mathrm{X}=\mathrm{CN}, \mathrm{CO}_{2} \mathrm{Et}\right)$ when react with cyclohexanone in anhydrous ammonium acetate afforded the spiropyridine oxoindole derivative $173^{[208]}$.

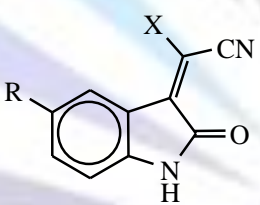

(172)

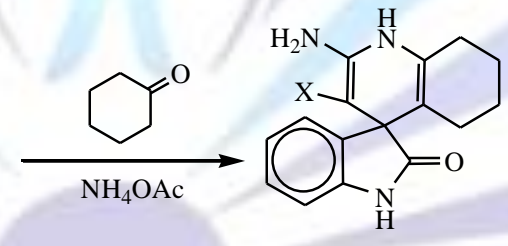

(173)

$(65-83 \%)$

2-(2-oxoindolin-3-yliden)acrylic acid was converted to spiropyridine oxoindole derivative 174 via the reaction with $\mathrm{HBr}$, aromatic amine and trifluoromethyl sulphonic acid ${ }^{[209]}$<smiles>O=C(O)/C=C1\C(=O)Nc2ccccc21</smiles><smiles>CC(C)(Br)[Mg]Br</smiles><smiles>[R]c1ccc2c(c1)C(=O)CC1(C2)NC(=O)c2ccccc21</smiles>

(174)

3-(2-oxopropylidene)indolin-2-one 12 reacted with 3-amino-1-phenyl pyrazole-5-one 175 to give the spiro[indolin3,4'-pyrazolo[3,4-b]pyridine]2,3' (2'H)dione 176 whereas, the reaction of 12 with pyrazolone 177 in $\mathrm{P}_{4} \mathrm{~S}_{10}$, ammonium 
acetate and/or $\mathrm{P}_{2} \mathrm{O}_{5} / \mathrm{H}_{3} \mathrm{PO}_{4}$ yielded spirothiine-, spiropyridine-, and spiropyrane oxoindoles derivative 178 respectively ${ }^{[210,211]}$. (Scheme 51)

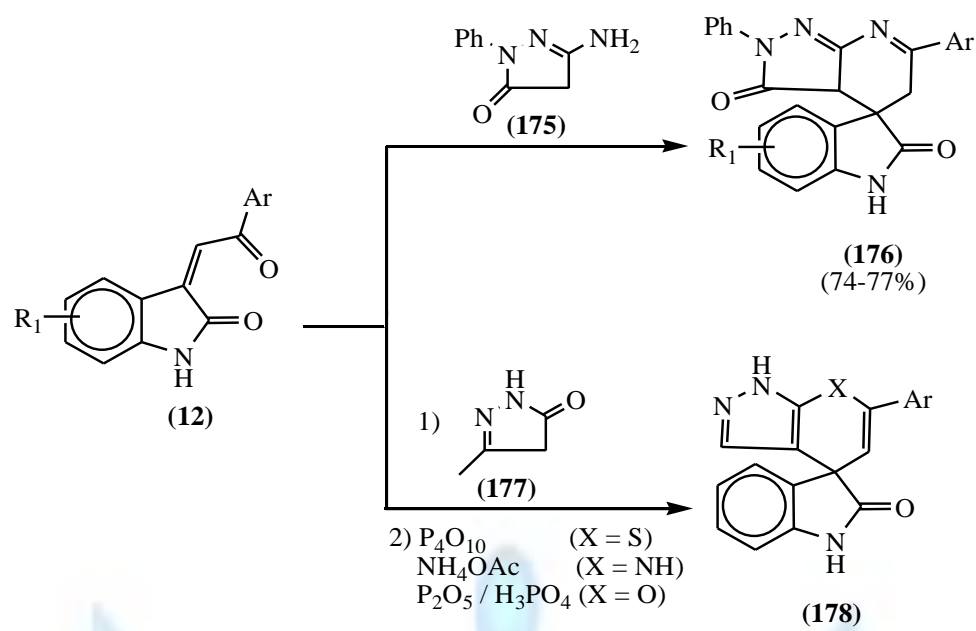

Scheme 51

\section{iii. Spiropyrane oxoindoles}

Three-component condensation of isatins with malononitrile or ethyl cyanoacetate and cyclic 1,3-diketone, cyclohexane-1,3-dione $\mathbf{1 7 9}$ or dimedone $\mathbf{1 8 0}$, on heating for a short time in ethanol in the presence of an equimolar amount of tris(2-hydroxyethyl)amine gave the corresponding 2-amino-3-R-5,6,7,8-tetrahydrospiro[chromene-4,3'-indole]$2^{\prime}, 5\left(1^{\prime} H, 4 H\right)$-diones 181 or 2 -amino-3-R-7,7-dimethyl-5,6,7,8-tetrahydrospiro[chromene-4,3'-indole]-2',5(1'H,4H)-diones 182. (Scheme 52)

Replacement of cyclic 1,3-diketones by acetylacetone in the condensation with isatin and malononitrile or ethyl cyanoacetate in the presence of tris(2-hydroxyethyl)amine in ethanol (short heating or reflux for 2 h) also resulted in $2^{\prime}$ amino-2-oxo-3'-R-1,2-dihydrospiro[indole-3,4'-pyran] derivatives 183 and 184. (Scheme 52)

When 2-(2-oxoindol-3-ylidene)malononitriles or ethyl 2-(2-oxoindol-3-ylidene)cyanoacetate derivatives 185 were used as a-cyanoethylene component in the Michael reactions with 1,3-dicarbonyl compounds in the presence of a catalytic amount of tris(2-hydroxyethyl)amine, yielded the same fused 4H-pyran derivatives 181-184. Obviously, compounds are key intermediates in the three-component condensation of isatins with $\mathrm{CH}$-active nitriles and 1,3diketones, which is consistent with the generally accepted mechanism of such reactions ${ }^{[212]}$.

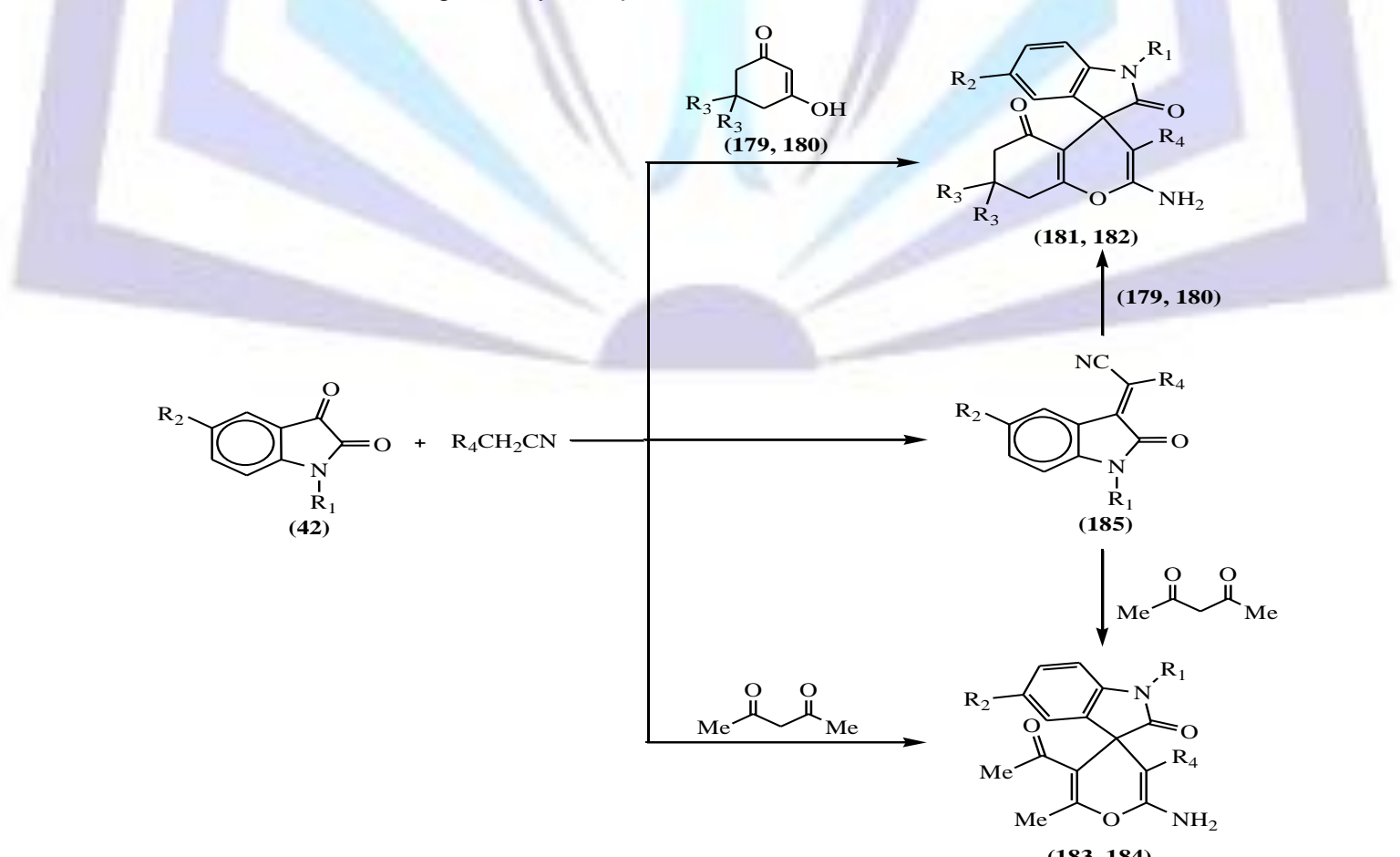

Scheme 52 
It has been reported that sharing of the indole-3-carbon atom during the formation of spiroindoline derivatives enhances the biological activity highly ${ }^{[6,26,27,35,213,214]}$.

Reaction of 2-hydroxynaphthalene-1,4-dione 186 and isatins in the presence of a catalytic amount of $p$ toluenesulfonic acid ( $p$-TSA) as an inexpensive and readily available catalyst proceeded smoothly in water at reflux for 24 $\mathrm{h}$ to produce spiro[dibenzo[ $b, 1]$-xanthene-13,3'-indoline]-2',5,7,12,14-pentaones 187 in 75-82\% yields (Scheme 53). Without $p$-TSA, for long periods of time $(60 \mathrm{~h})$, the yields of products were low $(<30 \%)$.

It is thought that compounds $\mathbf{1 8 7}$ result from initial addition of 2-hydroxynaphthalene-1,4-dione 186 to the isatin to yield intermediates $\mathbf{A}$, which react further with another molecule of $\mathbf{1 8 6}$. Finally, cyclization afforded the corresponding products 187. (Scheme 54)

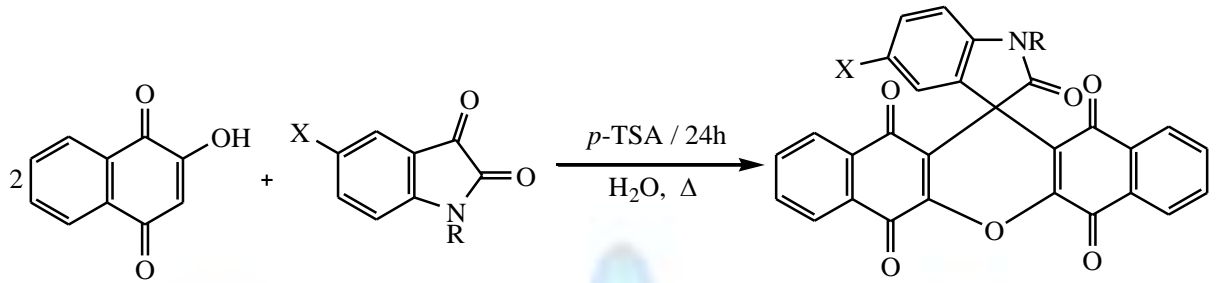

(187)

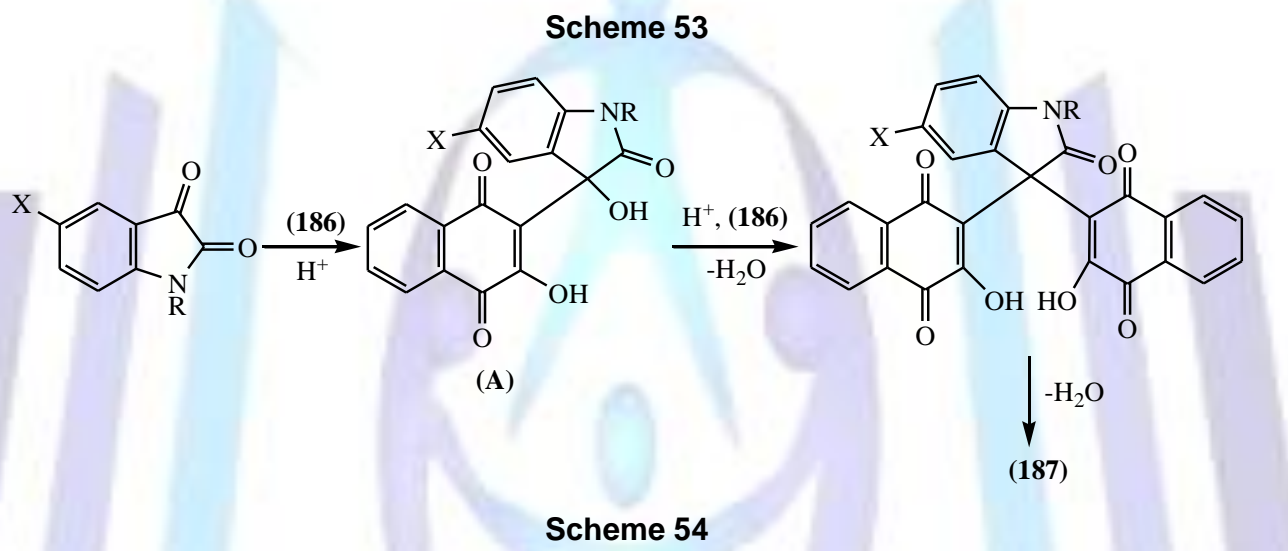

5-Fluoroisatin 188 reacted with ethyl cyanoacetate and substituted ketones affording the spiropyrane oxoindole derivative 189 which shows anticonvulsant activity ${ }^{[215]}$.

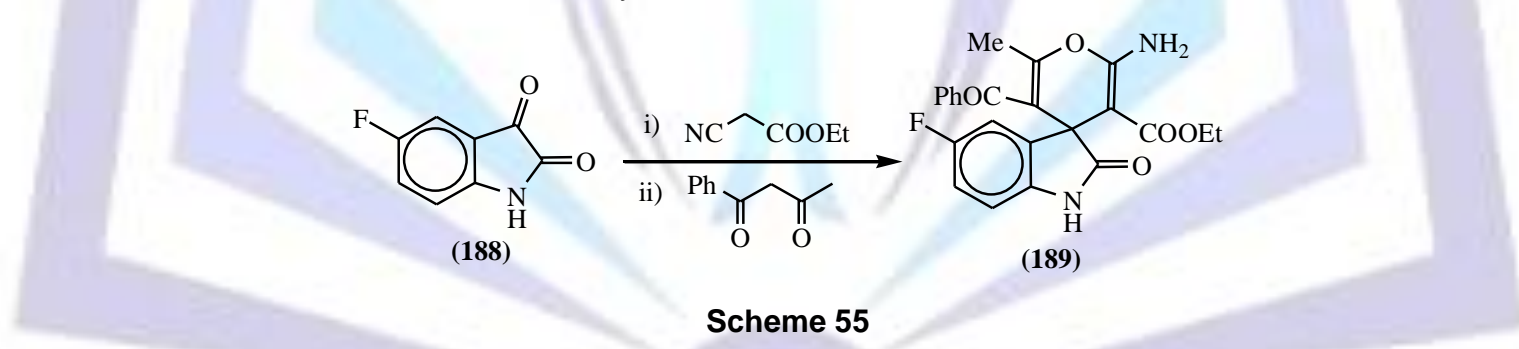

Novel nitrogen and phosphorus-containing lewis bases catalyzed [4+2]annulation of isatin with but-3-yn-2-one giving the corresponding spiro[indoline-3',2'-pyran]-2,4'-(3'H)dione $219^{[125]}$. (Scheme 56)

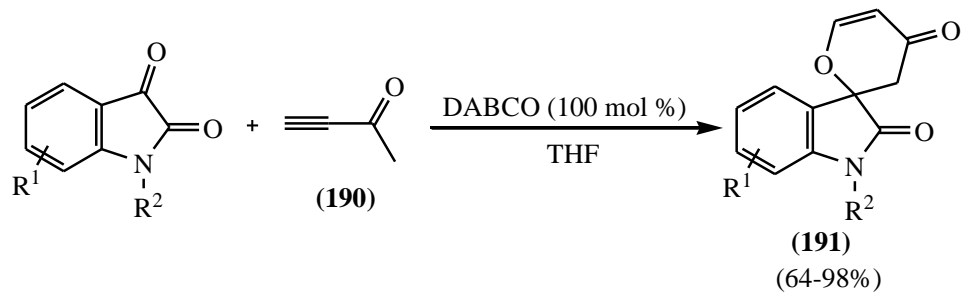

\section{Scheme 56}

The reaction of 2-oxoindol-3-ylidene malononitrile with ethyl acetoacetate ${ }^{[216]}$, cyclohexanone, cyclohexan-1,3dione ${ }^{[217]}$ and/or 4-hydroxycoumarin ${ }^{[218]}$ in the refluxing ethanol in the presence of piperidine afforded the corresponding spiropyrane oxoindole derivatives 192-195, respectively. (Scheme 57) 


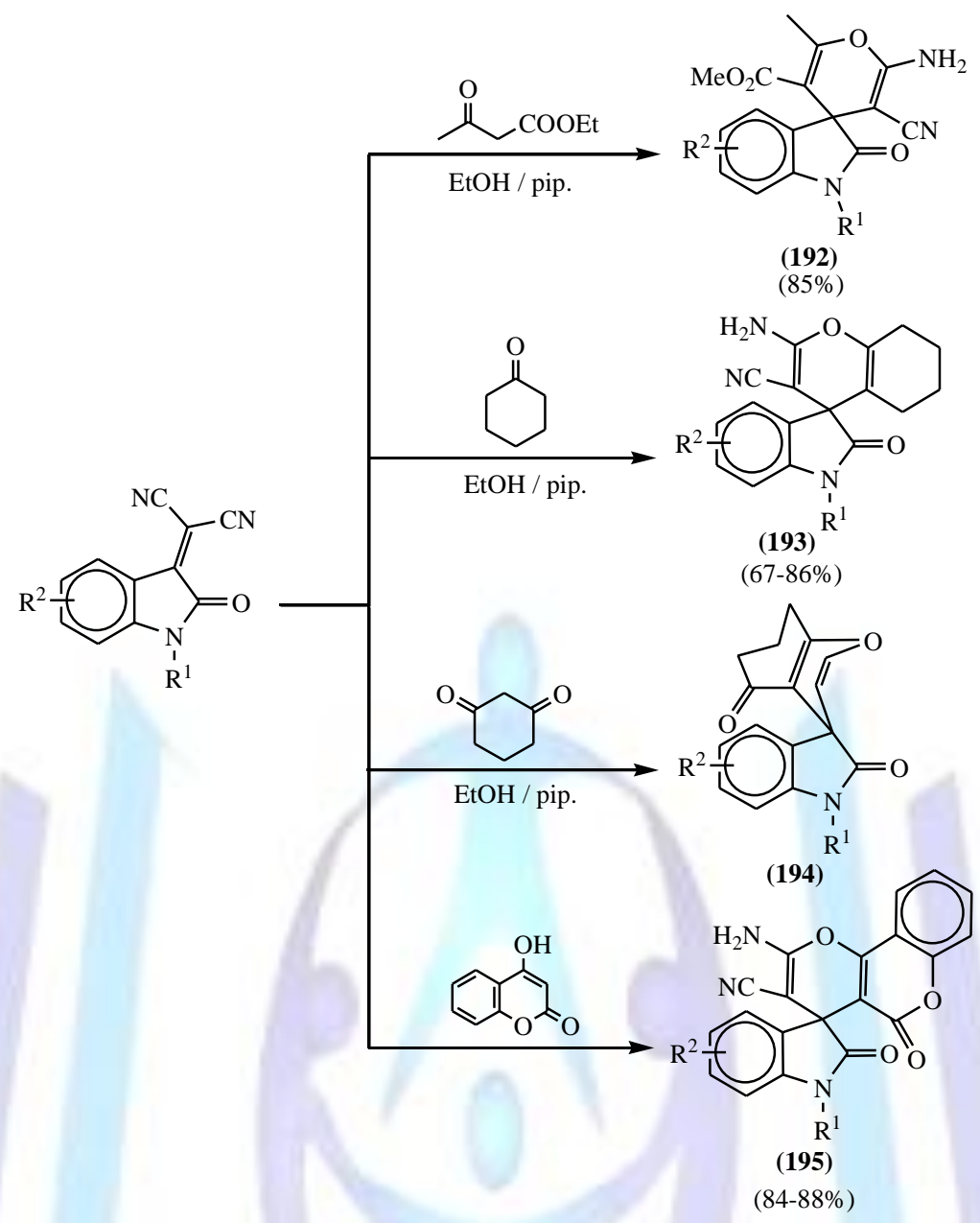

Scheme 57

Isatin reacted with $\mathrm{N}$-substituted pyrrolidin-2-one ${ }^{[219]} 190$ and/or with cyclohexan-1,3-dione ${ }^{[220]}$ and yielded the spiro pyrane oxoindole derivatives 196 and 197, respectively. (Scheme 58)

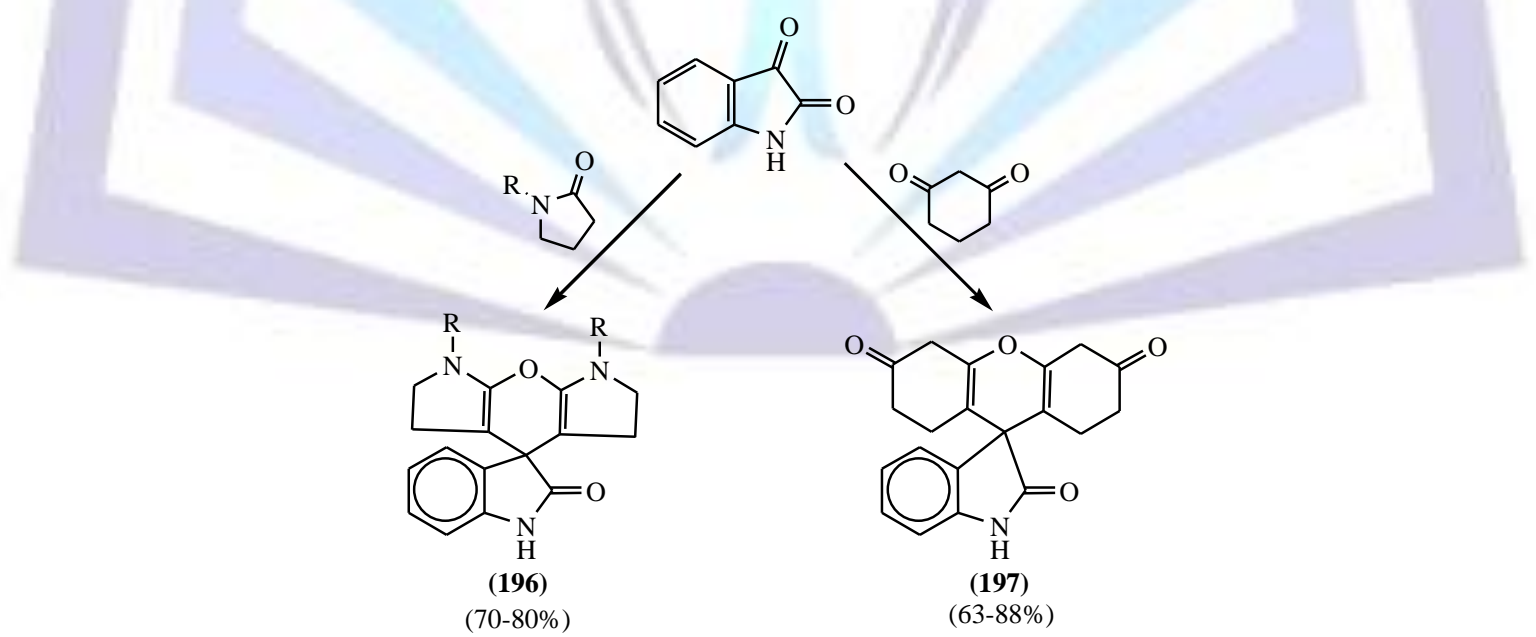

Scheme 58

\section{iv. Spiropyridazine oxoindole}

3-Cyanomethylidene oxoindole 198 derivatives were prepared in excellent yields utilizing DBU-promoted Knoevenagel condensation of isatin derivatives with active methylene reagents. The isolated products were then reacted with azaenamines 199 via a DBU-promoted Michael addition to yield spirocyclic 2-oxoindole derivatives 200,201 incorporated with 6-amino-4H-pyridazines ${ }^{[221]}$. (Scheme 59) 


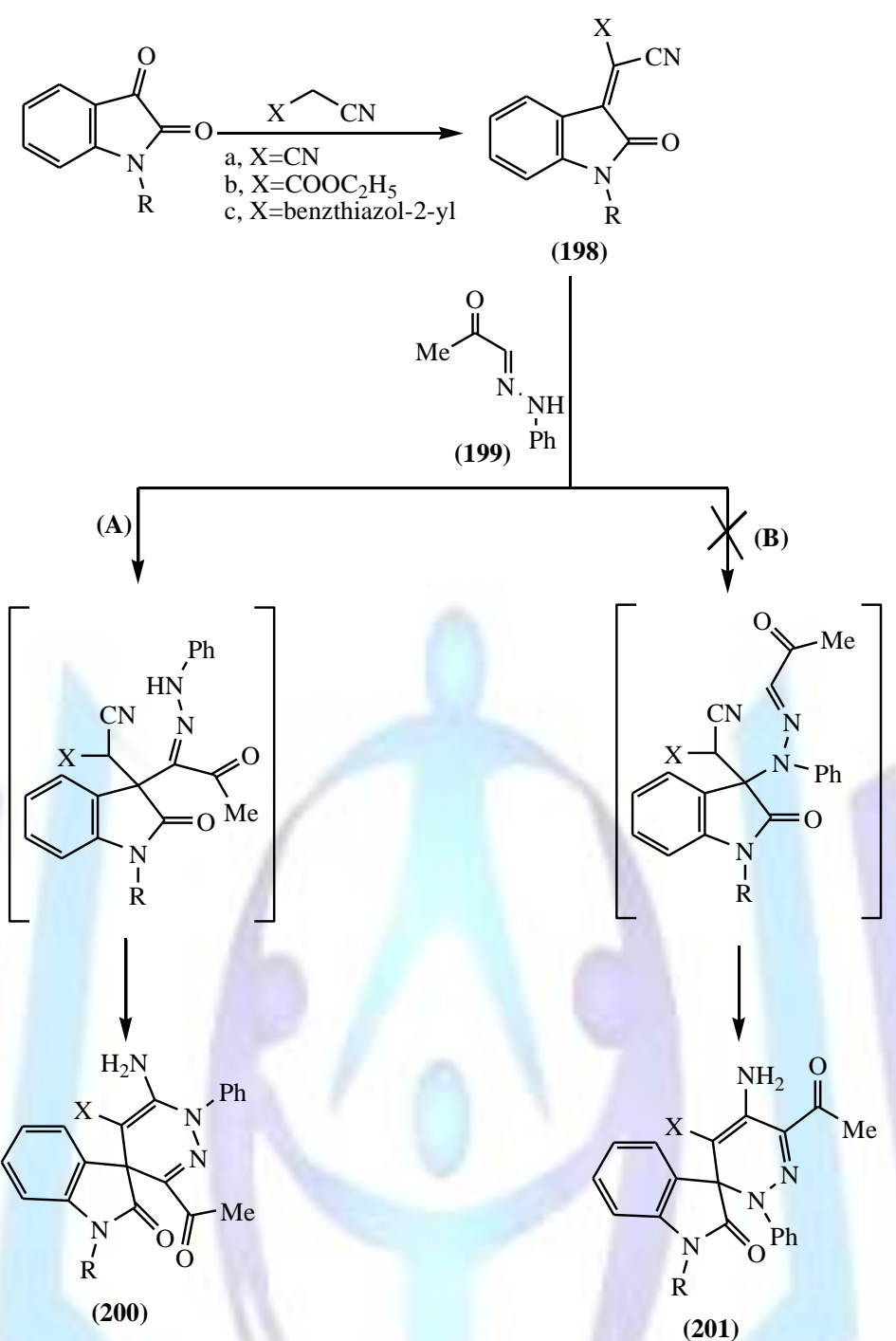

Scheme 59

Similarly azaenamine 202 reacted with 3-cyano methylidene-2-oxoindole 198 to yield the spiro compound 204 through the intermediate ${ }^{[205]}$ 203. (Scheme 60)

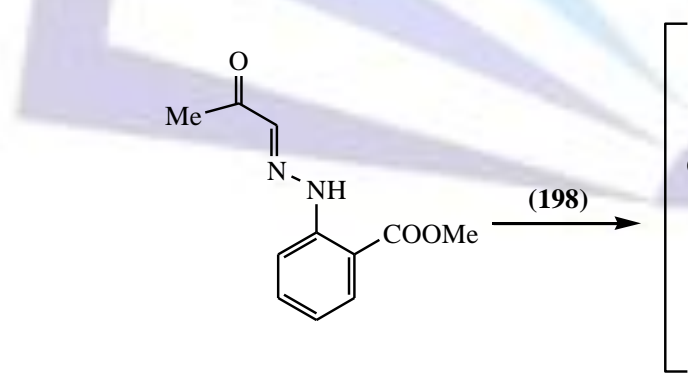

(202)

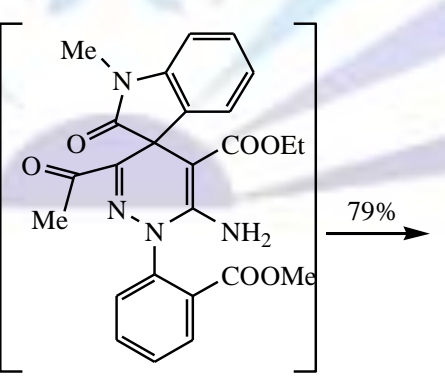

(203)

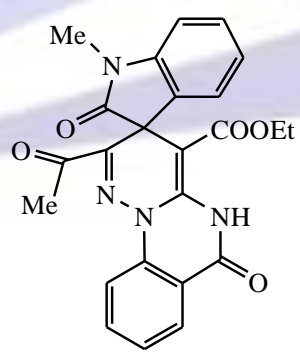

(204)

Scheme 60. Synthesis of compound 204.

\section{v. Spiropyrimidine oxoindoles}

3-Aroyl methylene-indole-2-ones $\mathbf{1 0 8}$ was synthesized and reacted with phenyl thiourea via conventional, microwave solution phase and microwave solid phase reactions to give the spyropyrimidine oxoindoles ${ }^{[173]}$ 205. (Scheme 61) 
<smiles>[X]c1ccc(C(=O)CC2(O)C(=O)Nc3ccc(-[X]4ccccc4[Y])cc32)cc1</smiles><smiles>O=C1Nc2ccccc2C12CC(c1cccc(I)c1)NC(=S)N2</smiles>

(205)

$\mathrm{X}=\mathrm{H}, 4-\mathrm{NO}_{2}$

$\mathrm{Y}=\mathrm{Br}, \mathrm{Cl}, \mathrm{CN}, \mathrm{OMe}$<smiles>[Y]c1ccc(C(=O)C=C2C(=O)Nc3ccc(C)cc32)cc1</smiles>

(108)

\section{Scheme 61}

Isatin when reacted with diamine 206 afforded spiro benzopyrimidine oxoindole derivative ${ }^{[22,223]} 207$. Moreover,

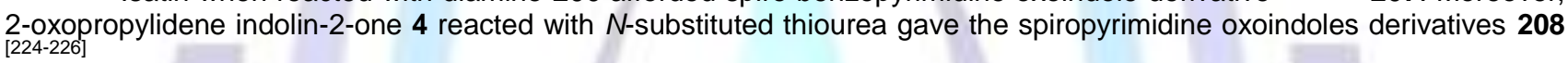<smiles>O=C1Nc2ccccc2C1=O</smiles><smiles>[R3]c1cc(Br)ccc1N</smiles><smiles>C#C</smiles><smiles>[R3]C1NC2(Nc3ccc(Br)cc31)C(=O)Nc1ccccc12</smiles>

(207)<smiles>[R3]C(=O)/C=C1\C(=O)N([2H])c2ccccc21</smiles>

(4)

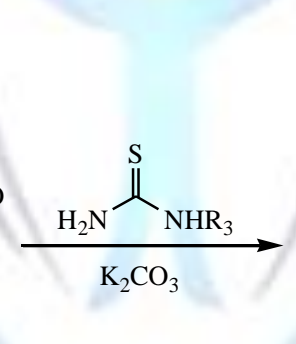

\section{le}

(1) The reaction of isatin with aromatic am
oxoindole derivative $210^{[227-229]}$. (Scheme 62)<smiles>[R]c1ccc2c(c1)C(=O)C(OCCN)N2[R1]([H])([H])[H]</smiles>

\section{Scheme 62}

A reaction of 1-amino-1H-benzimidazole-2-thiol 211 with 4-nitrobenzyl bromide yielded 1-amino-2-[(4nitrobenzyl)thio]-1H-benzimidazole 212, which underwent base-catalyzed cyclization with isatins 213 to give the corresponding spirocyclic $[1,3,4]$ thiadiazino[3,2-a]benzimidazoles 214. (Scheme 63)

A similar transformation in the base-catalyzed condensation of 4-amino-3-[(4-nitrobenzyl)thio]-4H-1,2,4-triazoles 215 with alkylisatins afforded spirocyclic triazolo [3,4-b][1,3,4]thiadiazines 217 (Scheme 64). 
Triazolothiadiazine $\mathbf{2 1 7}$ was also obtained by an independent synthesis from $\mathrm{N}$-triazolyl imine 218 and 4 nitrobenzyl bromide in the presence of $\mathrm{NaOH}$ (2 equiv.). In both cases, the reaction obviously proceeds through the formation of the corresponding acyclic $N$-benzylthiotriazolyl imine $216^{[230]}$.<smiles>[R]c1cc([R])c2c(c1)NC1(C(=O)N2[R])C([Y])C(C)(O)Sc2nc3ccccc3n21</smiles>

\section{Scheme 63}

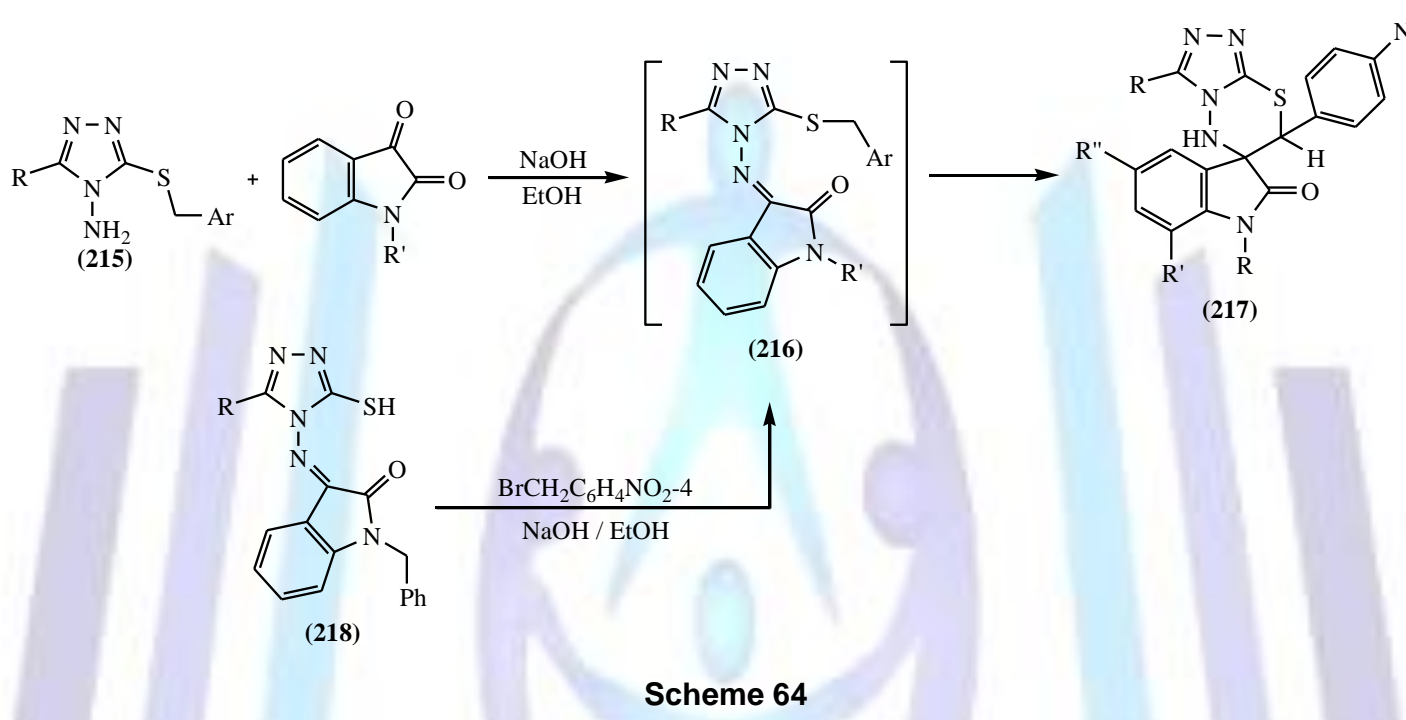

Spiro 1,3,5-triazine oxoindole 219, spiro 1,3,5-oxathiazine oxoindole 220 and spiro 1,2,3,4-tetrazine 221 were synthesized by treating isatin with urea, ethoxy thiocarbonyl cyanate and/or thioxodihydrazide followed by chloroacetic acid, respectively ${ }^{[231-233]}$. (Scheme 65)

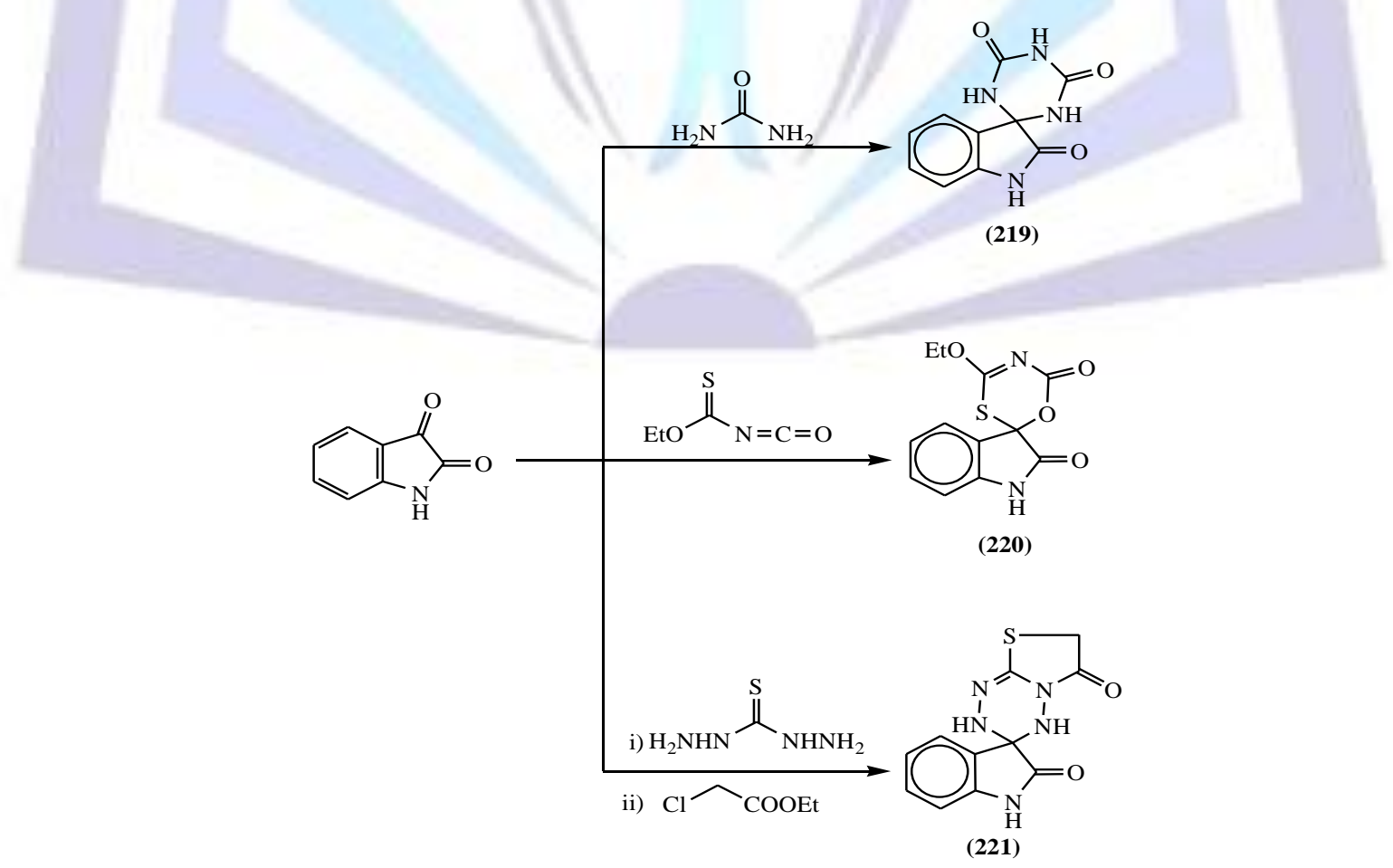

\section{Scheme 65}




\section{References:}

1. Sannigrahi, M. Tetrahedron 1999, 55, 9007.

2. James, D. M.; Kunze, H. B.; Faulkner, D. J. J. Nat. Prod. 1991, 54, 1137.

3. Kobayashi, J.; Tsuda, M.; Agemi, K.; Shigemiri, H.; Ishibashi, M.; Sasaki, T.; Mikami, Y. Tetrahedron 1991, $47,6617$.

4. Srivastav, N.; Mittal, A.; Kumar, A. J. Chem. Soc., Chem. Commun. 1992, 493.

5. Williams, R. M.; Cox, R. J. Acc. Chem. Res. 2003, 36, 127.

6. Da Silva, J. F. M.; Garden, S. J.; Pinto. A. C. J. Braz. Chem. Soc. 2001, 12, 273.

7. Basavaiah, D.; Reddy, K. R. Org. Lett. 2007, 9, 57.

8. Miyamoto, H.; Okawa, Y.; Nakazaki, A.; Kobayashi, S. Angew. Chem., Int. Ed. 2006, 45, 2274.

9. Nair, V.; Vellalath, S.; Poonoth, M.; Mohan, R.; Suresh, E. Org. Lett. 2006, 8, 507.

10. Ding, K.; Lu, Y.; Nikolovska-Coleska, Z.; Wang, G.; Qiu, S.; Shangary, S.; Gao, W.; Qin, D.; Stuckey, J.; Krajewski, K.; Roller, P. P.; Wring, S. J. Med. Chem. 2006, 49, 3432.

11. Teng; Zhang, H.; Mendonca, A. Molecules 2006, 11, 700.

12. Lo, M. M.-C.; Neumann, C. S.; Nagayama, S.; Perlstein, E. O.; Sclreiber, S. L. J. Am. Chem. Soc. 2004, 126, 16077.

13. Hilton, S. T.; Ho, T. C. T.; Pljevaljcic, G.; Jones, K. Org. Lett. 2000, 2(17), 2639.

14. Malinakova, H. C.; Liebeskind, L. S. Org. Lett. 2000, 2, 4083.

15. Nakagawa, M.; Taniguchi, M.; Sodeoka, M.; Ito, M.; Yamaguchi, K.; Hino, T. J. Am. Chem. Soc. 1983, 105, 3709.

16. Chang, K.-T.; Shechter, H. J. Am. Chem. Soc. 1979, 101, 5084.

17. Huang, A.; Kodanko, J. J.; Overman, L. E. J. Am. Chem. Soc. 2004, 126, 14043.

18. Bagul, T. D.; Lakshmaiah, G.; Kawabata, T.; Fuji, K. Org. Lett. 2002, 4, 249.

19. Dounay, A. B.; Overman, L. E. Chem. Rev. 2003, 103, 2945.

20. Trost, B. M.; Frederiksen, M. U. Angew. Chem. 2005, 117, 312; Angew. Chem., Int. Ed. 2005, 44, 308.

21. Yong, S. R.; Willams. M. C.; Pyne, S. G.; Ung, A. T.; Skelton, B. W.; White, A. H.; Turner, P. Tetrahedron 2005, 61, 8120 .

22. Beccalli, E. M.; Cleriici, F.; Gelmi, M. L. Tetrahedron 2003, 59, 4615.

23. Kawasaki, T.; Ogawa, A.; Terashima, R.; Saheki, T.; Ban, N.; Sekiguchi, H.; Sakaguchi, K.; Sakamoto, M. J. Org. Chem. 2005, 70, 2957.

24. Mao, Z.; Baldwin, S. W. Org. Lett. 2004, 6, 2425.

25. Somei, M.; Yamada, F.; Izumi, T.; Nakajou, M. Heterocycles 1997, 45, 2327.

26. Abdel-Rahman, A. H.; Keshk, E. M.; Hanna, M. A.; El-Bady, Sh. M. Bioorg. Med. Chem. 2004, $12,2483$.

27. Kang, T.-H.; Matsumoto, K.; Murakami, Y.; Takayama, H.; Kitajima, M.; Aimi, N.; Watanabe, H. Eur. J. Pharmacol. 2002, 444, 39.

28. Ma, J.; Hecht, S. M. Chem. Commun. 2004, 1190.

29. Zhu, S.-L; Jia, S.-J.; Zhang, Y. Tetrahedron 2007, 63, 9365.

30. Kumar, R. S.; Perumal, S. Tetrahedron Lett. 2007, 48, 7164.

31. Redkin, R. Gr.; Shemchuk, $\quad$ L. A.; Chernykh, V. P.; Shishkin, O. V.; Shishkina, S. V. Tetrahedron 2007, 63, 11444.

32. Shanthi, G.; Subbulakshmi, G.; Perumal, P. T. Tetrahedron 2007, 63, 2057.

33. Sundberg, R. J. The Chemistry of Indoles; Academic Press: New York, 1996.

34. Joshi, K. C.; Chand, P. Pharmazie 1982, 37.

35. Khafagy, M. M.; El-Wahas, A. H. F. A.; Eid, F. A.; El-Agrody, A. M. Farmaco 2002, 57, 715.

36. Mohammadi, A. A.; Dabiri, M.; Qaraat, H. Tetrahedron 2009, 65, 3804. 
Bose, A. K.; Pednekar, S.; Ganguly, S. N.; Chakraborty, G.; Manhas, M. S. Tetrahedron Lett. 2004, 45, 8351. Varughese, D. J.; Manhas, M. S.; Bose, A. K. Tetrahedron Lett. 2006, 47, 6795. Toda, F.; Tanaka, K.; Sekikawa, A. J. Chem. Soc., Chem. Commun. 1987, 279. Bazgir, A.; Mohammadi Khanaposhtani, M.; Abolhasani Soorki, A. Bioorg. Med. Chem. Lett. 2008, 18, 5800. Bazgir, A.; Seyyedhamzeh, M.; Yasaei, Z.; Mirzaei, P. Tetrahedron Lett. 2007, 48, 8790. Sayyafi, M.; Seyyedhamzeh, M.; Khavasi, H. R.; Bazgir, A. Tetrahedron 2008, 64, 2375. Dabiri, M.; Arvin-Nezhad, H.; Khavasi, H. R.; Bazgir, A. J. Heterocycl. Chem. 2007, 44, 1009. Dabiri, M.; Azimi, S. C.; Arvin-Nezhad, H.; Bazgir, A. Heterocycles 2008, 75, 87. Dabiri, M.; Delbari, A. S.; Bazgir, A. Synlett 2007, 821. Dabiri, M.; Arvin-Nezhad, H.; Khavasi, H. R.; Bazgir, A. Tetrahedron 2007, 63, 1770. Dabiri, M.; Delbari, A. S.; Bazgir, A. Heterocycles 2007, 71, 543. Ghahremanzadeh, R.; Imani Shakibaei, G.; Bazgir, A. Synlett 2008, 1129. Bazgir, A.; Noroozi Tisseh, Z.; Mirzaei, P. Tetrahedron Lett. 2008, 49, 5165. Jadidi, K.; Ghahremanzadeh, R.; Bazgir, A. Tetrahedron 2009, 65, 2005. Dabiri, M.; Azimi, S. C.; Khavasi, H. R.; Bazgir, A. Tetrahedron 2008, 64, 7307. Jadidi, K.; Ghahremanzadeh, R.; Bazgir, A. J. Comb. Chem. 2009, 11, 341. Ghahremanzadeh, R.; Sayyafi, M.; Ahadi, S.; Bazgir, A. J. Comb. Chem. 2009, 11, 393. Hailer, N.; Holzer, W. Sci. Synthesis 2004, 16, 125. Woo, G. H. C.; Snyder, J. K.; Wan, Z.-K. Prog. Heterocycl. Chem. 2002, 14, 279. Cignarella, G.; Barlocco, D. J. Heterocycl. Chem. 2002, 39, 545.

Ghozlan, S. A. S.; Mohamed, M. H.; Abdelmoniem, A. M.; Abdelhamid, I. A. ARKIVOC 2009, x, 302. Abdelhamid, I. A.; Ghozlan, S. A. S.; Kolshorn, H.; Meier, H.; Elnagdi, M. H. Heterocycles 2007, 71, 2627. Al-Awadi, N. A.; Ibrahim, M. I.; Abdelhamid, I. A.; Elnagdi, M. H. Tetrahedron 2008, 64, 8202. Ghozlan, S. A. S.; Abdelhamid, I. A.; Gaber, H; Elnagdi, M. H. J. Chem. Res. 2004, 12, 789. Ghozlan, S. A. S.; Abdelhamid, I. A.; Elnagdi, M. H. J. Heterocycl. Chem. 2005, 42, 1185. Ghozlan, S. A. S.; Abdelhamid, I. A.; Al-Dib, H. I.; Elnagdi, M. H. ARKIVOC 2006, xv, 53. Yong, S. R.; Ung, A. T.; Pyne, S. G.; Skelton, B. W.; White, A. H. Tetrahedron 2007, 63, 1191. Marti, C.; Carreira, E. M. J. Am. Chem. Soc. 2005, 127, 11505.

Robertson, D. W.; Krushinski, J. H.; Pollock, G. D.; Wilson, H.; Kauffman, R. F.; Hayes, J. S. J. Med. Chem. 1987, 30, 824.

Feldman, K. S.; Vidulova, D. B.; Karatjas, A. G. J. Org. Chem. 2005, 70, 6429.

7. Feldman, K. S.; Karatjas, A. G. Org. Lett. 2006, 8, 4137.

Ghozlan, S. A. S.; Abdelhamid, I. A.; Hassaneen, H. M.; Elnagdi, M. H. J. Heterocycl. Chem. 2007, 44,105. Abdelhamid, I. A. Synlett 2009, 625.

Ghozlan, S. A. S.; Abdelhamid, I. A.; Elnagdi, M. H. ARKIVOC 2006, xiii, 147. Al-Awadi, N.; Abdelhamid, I. A.; Al-Etaibi, A.; Elnagdi, M. H. Synlett 2007, 2205. Al-Awadi, N. A.; Abdelkhalik, M. M.; Abdelhamid, I. A.; Elnagdi, M. H. Synlett 2007, 2979. Warea, M.; Madjeb, B.; Pokalwara, R.; Kakadea, G.; Shingarea, M. Bull. Cat. Soc. Ind. 2007, 6, 104. Yeom, C.-E.; Kim, M. J.; Kim, B. M. Tetrahedron 2007, 63, 904. Ramin, G.; Somayeh, A.; Ghazaleh, I. S.; Ayoob, B. Tetrahedron Lett. 2010, 51, 499. Franke, A. Justus Liebigs Ann. Chem. 1978, 5, 717. Bennet, G. B.; Mason, R. B.; Shapiro, M. J. J. Org. Chem. 1978, 43, 4383. Joshi, K. C.; Jain, R.; Arora, S. Heterocycles 1987, 26, 1853. 
79. Martin, M.; Nadler, G.; Zimmermann, R. Eur. Pat. Appl. Ep. 1989, 303, 418, 59.

80. Ponnusamy, S.; Vadivel, V.; Baby, V. Tetrahedron 2006, 62, 4342.

81. Kandapalam, A. P. L.; Asit, B. M.; Ponnusamy, S. Tetrahedron Lett. 2011, 52, 3610.

82. Mesropyan, E. G.; Ambartsumyan, G. B.; Avetisyan, A. A.; Sarkisyan, M. G.; Galstyan, A. S. Zh. Org. Khim. 2005, 41(1), 150.

83. Kennewell, P. D.; Miller, D. J.; Scrowston, R. N.; Westwood, R. J. Chem. Res. (S) 1995, 396.

84. Jain, R. S. Ind. J. Heterocycl. Chem. 1992, 2, 59.

85. Coda, A. C.; Desimoni, G.; Riguetti, P. P.; Tacconi, G.; Dradi, E. Gazz. Chim. Ital. 1983, 113, 191.

86. Koch, T. H.; Olesen, J.; Foy, J. J. Org. Chem. 1975, 40, 117.

87. Dipak, P.; Sunil, G. Tetrahedron 2004, 60, 4909.

88. Graf, R. Liebig's Ann. Chem. 1963, 661, 111.

89. Moriconi, E. J.; Kelley, J. F. J. Am. Chem. Soc. 1966, 88, 3657.

90. Bose, A. K.; Garratt, G.; Pelosi, J. J. J. Org. Chem. 1963, 28, 730.

91. Singh, S. B.; Mehrotra, K. N. Can. J. Chem. 1982, 60, 1901.

92. Singh, G. S.; Mehrotra, K. N. Indian J. Chem. 1985, 24B, 129.

93. Singh, G. S.; Singh, T.; Lakhan, R. Indian J. Chem. 1997, 36B, 951-954.

94. Singh, G. S.; Heterocycl. Chem. 2000, 37, 1355.

95. Alonso, E.; Del Pozo, C.; Gonzalez, J.; J. Chem. Soc. Perkin Trans. 2002, 1, 571.

96. Azizian, J.; Sarrafi, M.; Mehrdad, K. Indian J. Chem. 2000, 39B, 304.

97. Arjona, O.; Csaky, A. G.; Murcia, M. C.; Plumet, J. Tetrahedron Lett. 2002, 43, 6405.

98. Nishikawa, T.; Kajii, S.; Isobe, M. Chem. Lett. 2004, 33, 440.

99. Zanobini, A.; Gensini, M.; Magull, J.; Vidovic, D.; Kozhushkov, S. I.; Brandi, A.; De Meijere, A. Eur. J. Org. Chem. 2004, 4158.

100. Nishikawa, T.; Kajii, S.; Isobe, M. Synlett 2004, (11), 2025.

101. Khasanov, A. B.; Ramirez-Weinhouse, M. M.; Webb, T. R.; Thiruvazhi, M. J. Org. Chem. 2004, 69, 5766.

102. Singh, G. S.; Mmolotsi, B. J.; J. Heterocycl. Chem. 2006, 43, 1665.

103. Singh, G.S. Tetrahedron 2003, 59, 7631.

104. Singh, G. S.; D'hooghe, M.; De Kimpe, N. in: Katritzky, A. R.; Ramsden, C.; Scriven, E. F. V.; Taylor (Eds.), R. Comprehensive Heterocyclic Chemistry III, Elsevier, New York, 2008, 2, 1.

105. Staudinger, H. Liebig's Ann. 1907, 356, 51.

106. Girija, S. S.; Patrick, L. Eur. J. Med. Chem. 2009, 44, 2265.

107. Skiles, J. W.; McNeil, D. Tetrahedron Lett. 1990, 31, 7277

108. Manju, P.; Neeraj, K. S.; Priyanka, K. K. J. J. Adv. Sci. Res. 2011, 2(2), 35.

109. Pai, N. R.; Suryanvansi, J. P. Ind. J. Chem. 2006, 25B, 1226.

110. Zhang, X.-C.; Cao, S.-H.; Wei, Y.; Shi, M. Chem. Commun. 2011,1548.

111. Zhang, X.-C.; Cao, S.-H.; Wei, Y.; Shi, M. Org. Lett. 2011, 13, 1142.

112. Al-Thebeiti, M. S.; El-Zohry, M. F. Heterocycles 1995, 41, 2475.

113. Wang, L; Zhang, Y.; Hu, H. -Y.; Fun, H. K.; Xu, J.-H. J. Org. Chem. 2005, 70, 3850.

114. Booker-Milburn, K. I.; Fedoulo, M.; Paknoham, S. J.; Strachan, J. B.; Melvilleb, J. L.; Voyleb, M. Tetrahedron Lett. 2000, 41, 4657.

115. Xue, J.; Zhang, Y.; Wang, X.; Fun, H. K.; Xu, J.-H. Org. Lett. 2000, 2, 2583.

116. Tratrat, C.; Giorgi-Renault, S.; Husson, H.-P. J. Org. Chem. 2000, 65, 6773.

117. Marti, C.; Carreira, E. M. Eur. J. Org. Chem. 2003, 12, 2209.

118. Toyota, M.; Ihara, M. Nat. Prod. Rep. 1998, 15, 327. 
119. Dounary, A. B.; Hatanaka, K.; Kodanko, J. J.; Oestreich, M.; Pfeifer, L. A.; Weiss, M. M. J. Am. Chem. Soc. 2003, 125, 6261.

120. Balogh, M.; Laszlo, P. Organic Chemistry Using Clays; Springer: New York, NY, 1993, $29,184$.

121. Corma, A. Chem. Rev. 1995, 95, 559.

122. Chakrabarty, M.; Sarkar, S. Tetrahedron Lett. 2003, 44, 8131.

123. Dintzner, M. R.; Morse, K. M.; McClelland, K. K.; Coligado, D. M. Tetrahedron Lett. 2004, 45, 78.

124. Ponnusamy, S.; Vadivel, V. Tetrahedron 2008, 64, 3322.

125. Lian, Z.; Shi, M. Eur. J. Org. Chem. 2012, 3, 581.

126. Heindel, N. D.; Minatell, J. A. J. Pharm. Sci. 1981, 70, 84.

127. Soliman, F. S. G.; Salama, H. M. pharmazie 1983, 38, 585.

128. Fokas, D.; Ryan, W. J.; Casebier, D. S.; Coffen, D. L. Tetrahedron Lett. 1998, 39, 2235.

129. Fokas, D.; Coffen, D. L.; Ryan, W. J. WO; 99129041999 [C. A.: 130,237550v].

130. Jeyaperumal, K. S.; Stephen, M. R.; Jeyaraman, S.; Subbu, P.; Subramanian, N. Chem. Central J. 2011, 5, 45.

131. Garima, S. S.; Vasanth, K.; Habibah, A. W.; Mohd, M. R.; Hoong-Kun, F. Acta. Cryst. 2012, E68, 2769.

132. Gowri, S.; Gunasundari, T.; Raghunathan, R. Tetrahedron Lett. 2007, 48, 319.

133. Casaschi, A.; Desimoni, G.; Faita, G.; Invernizzi, A. G.; Grunanger, P. Heterocycles 1994, $37,1673$.

134. Neelakandan, V. L.; Prakasam, T.; Paramasivan, T. P. Tetrahedron Lett. 2010, 51, 1064.

135. Kumar, R. R.; Perumal, S.; Senthilkumar, P.; Yogeeswari, P.; Sriram, D. Eur. J. Med. Chem. 2009, 44, 3821.

136. Shanmugam, P.; Viswambharan, B.; Madhavan, S. Org. Lett. 2007, 9, 4095.

137. Shanmugam, P.; Viswambharan, B.; Selvakumar, K.; Madhavan, S. Tetrahedron Lett. 2008, 49, 2611.

138. Murugan, R.; Anbazhagan, S.; Narayanan, S. S. Eur. J. Med. Chem. 2009, 44, 3272.

139. Babu, A. R. S.; Raghunathan, R. Tetrahedron Lett. 2007, 48, 6809.

140. Bovio, B.; Locchi, S. J. Chem. Crystallogr. 2002, 32, 69.

141. Rehn, S.; Bergman, J.; Stensland, B. Eur. J. Org. Chem. 2004, 2, 413.

142. Babu, A. R. S.; Raghunathan, R. Tetrahedron 2007, 63, 8010.

143. Raju, S. K.; Stephen, M. R.; Subbu, P.; Debjani, B.; Perumal, Y.; Dharmarajan, S. Eur. J. Med. Chem. 2010, 45, 411.

144. Raju, S. K.; Subbu, P. Tetrahedron Lett. 2007, 48, 7164.

145. Mehdi, G.; Ahmed, Y.; Seyed, J. T. R.; Abuzar, T. Tetrahedron Lett. 2009, 50, 4724.

146. Bergman, J.; Stalhandske, C.; Vallberg, H. Acta. Chem. Scand. 1997, 51, 753.

147. Grigg, R.; Aly, M. F.; Sridharan, V.; Thianpatanagul, S. J. Chem. Soc. Chem. Commun 1984, 3, 182.

148. Coulter, T.; Grigg, R.; Malone, J. F.; Sridharan, V. Tetrahedron Lett. 1991, 32, 5417.

149. Nyergers, M.; Gajdics, L.; Szöllösy, A.; Töke, L. Synlett. 1999, 111.

150. Agarwal, S.; Pande, A.; Saxena, V. K.; Chowdhury, S. R. Indian Drugs 1985, 22, 633.

151. Gisele, Z. S.; Luana, B. P.; Daniele, G.; Thaiana, E. F. M.; Nubia, M. R.; Angelo, C. P.; Margarete, M. T.; Roberto, T. S. Pharmacology Biochemistry and Behavior 2007, 86, 678.

152. Kara, L. V.; Julie, M. L.; Marie, R.; Stephen, G. P.; John, B. B. Bioorg. Med. Chem. 2007, 15, 931.

153. Botov, V. V.; Nambelbal, A.; Drogovoz, S. M.; Vereitinova, V. P. Khim. Farm. Zh. 1986, 20, 1463 [C. A.: $106,196188 \mathrm{~s}]$.

154. Edeliza, L. D. S.; Walter, A. G.; Núbia, M. R.; Heloysa, M. C. A. Journal of Molecular catalysis A: Chemicals 2008, 295, 18.

155. Sakai, S.; Aimi, N.; Kubo, A.; Kitagawa, M.; Hanasawa, M.; Katano, K.; Yamaguchi, K.; Haginiwa, J. Chem. Pharm. Bull. 1975, 23, 2805.

156. Rucker, J. W.; Freeman, H. S.; Hsu, M. N. Text. Chem. Color 1992, 24, 66. 
157. Kaupp, G.; Matties, D. Chem. Ber. 1987, 120, 1897.

158. Niume, K.; Toda, F.; Uno, K.; Hasegawa, M.; Iwakura, Y. J. Polymer Sci. Polymer Chem. Ed. 1983, $21,615$.

159. Ivaschchenko, A. V.; Agafonova, I. F. Khim. Gaterotsikl Soedin 1981, 249 [C. A.: 1981, 95,7219y].

160. Ivaschchenko, A. V.; Drushlyak, A.-G.; Titov, V. V. Khim. Gaterotsikl Soedin 1984, 5, 667 [C. A.: 1984 , 101,110872x].

161. Drushlyak, A.-G.; Ivaschchenko, A. V.; Titov, V. V. Khim. Gaterotsikl Soedin 1984, 1399 [C. A.: 1985, 102,113423h].

162. Sarkin, G. Y.; Al-Badri, H. T. J. Heterocycl. Chem. 1980, 17, 813.

163. Joshi, K. C.; Chand, P.; Dandia, A. Indian J. Chem. 1984, 23B, 743.

164. Xiao-Nan, Z.; Yong-Xiao, L.; Zhan-Hui, Z. Tetrahedron 2011, 67, 7426.

165. Hui, C.; Da-Qing, S. J. Heterocyclic Chem. 2013, 50, 56.

166. Cornforth, J. W. J. Chem. Soc. Perkin Trans 1 1976, 2004.

167. Bradman, H. A. J. Heterocycl. Chem. 1973, 10, 383.

168. Kamlet, M. J.; Kaplan, L. A. J. Org. Chem. 1957, 22, 576.

169. Mukherjee, S.; Raunak; Dhawan, A.; Poonam; Prasad, A. K.; Olsen, C. E.; Cholli, A. L.; Errington, W.; Raj, H. G.;Watterson, A. C.; Parmar, V. S. Indian J. Chem. 2004, 43B, 2670.

170. Venkatachalapathy, C.; Thirumalaikumar, M.; Muthusubramanian, S.; Pitchumani, K.; Sivasubramanian, S. Synth. Commun. 1997, 27, 4041.

171. Ciesielski, W.; Kundzin, Z. H.; Tasz, M.; Drabowicz, J. Can. J. Chem. 1990, 68, 679. [C. A.: 1990, 113, 108479].

172. Raunak; Vineet, K.; Shubhasish, M.; Poonam; Ashok, K. P.; Carl, E. O.; Susan, J. C. S.; Sunil, K. S. Arthur, C. W.; William, E.; Virinder, S. P. Tetrahedron 2005, 61, 5687.

173. Mishra, A. D. J. Nepal. Chem. Soc. 2009, 24, 49.

174. Joshi, K. C.; Jain, R.; Sharma, K. J. Indian chem. Soc. 1988, 65, 640.

175. Joshi, K. C.; Jain, R.; Garg, S.; Arora, S. J. Indian chem. Soc. 1989, 66, 176.

176. Joshi, K. C.; Dandia, A.; Bhagat, S. Indian J. Chem. 1992, 31B, 98.

177. Otomasu, H.; Ohmiya, S. Japan Kokai 1975, 75, 137, 976 [C. A.: 1975, 85,21357s].

178. Joshi, K. C.; Pardasani, R. T.;Dandia, A.; Bhagat, S. Heterocycles 1981, 16, 1555.

179. Bhawana, T.; Devendra, S.; Gangotri, P.; Talesara, G. L. Ind. J. Chem. 2010, 49B, 368.

180. Alauddin, S.; Hayat, F. Indian. J. Sci. Res. 2012, 3(1), 191.

181. Rani, H. S.; Mogilaiah, K.; Rao, I. S.; Sreenivasulu, B. Indian, J. Chem. 1995, 34B, 1035.

182. Mostafa, M. H. K; Foziah, A. A. J. Soudi. Chem. Soc. 2010, 14, 33.

183. Althebeiti, M. S.; El-Zohry, M. F. Phosphorus, Sulfur, Silicon Relat. Elem. 1994, 88, 251.

184. Wagner, H. U.S. Patent 4405 780, 1983; [C. A.: 1983, 100, 6550].

185. Omodei-Sale, A.; Consonni, P.; Lerneer, U. S. Patent, 4075 341, 1978; [C. A.: 1978, 89, 24316w].

186. Maclauchlin, C.; Hall, I. H.; Izydore, R. A. Arch. Pharm. 1999, 332, 225.

187. Clitherow, J. W.; Bradshaw, J.; Price, B. J.; Martin-Schmith, M.; Mackinnon, J. W. M.; Judd, D. B.; Hayes, R.; Carey, L. (Glaxo Group Ltd.) Eur. Patent 16565, 1980; [C. A.: 1980, 94, 192345b].

188. Hall, I. H.; Wong, O. T.; Simlot, R.; Miller, M. C.; Izydore, R. A. Anticancer Res. 1992, 12, 1355.

189. Ito, Y.; Nie, Y.; Kobayashi, S.; Ohno, M. Tetrahedron Lett. 1979, 2521.

190. Kajopadhye, M.; Popp, F. D. J. Heterocycl. Chem. 1985, 22, 93.

191. Yousef, M. S. K. J. Chem. Tech. Biotechnol. 1981, 31, 363.

192. Yousef, M. S. K. Rev. Roum. Chim. 1981, 26, 471.

193. Tomchin, A. B. Zh. Org. Khim.1981, 17, 1561.

194. Tomchin, A. B. Zh. Org. Khim.1981, 17, 589. 
195. Tomchin, A. B.; Dmitrukha, V. S. Zh. Org. Khim.1975, 11, 184.

196. Somogyi, L. Liebigs Ann. Chem. 1993,931.

197. Islam, M. R.; Mohsin, M. Bangladesh J. Pharmacol. 2007, 2, 7.

198. Egle, M. B.; Francesca, C.; Maria, L.G. Tetrahedron 2003, 59, 4615.

199. Pandeya, S. N.; Mishra, B.; Singh, P. N.; Rupainwar, D. C. Pharmacol. Res. 1998, 37, 17.

200. Kondo, Y.; Mitadera, Y.; Nozoe, S. Yakugaku Zasshi 1985, 105, 724 [C. A.: 1985, 105,133701n].

201. Wenkert, E.; Liu, S. Synthesis 1992, 323.

202. Ahadi, S.; Khavasi, H. R.; Bazgir, A. Chem. Pharm. Bull. 2008, 56, 1328.

203. Ghahremanzadeh, R.; Azimi, S. A.; Gholami, N.; Bazgir, A. Chem. Pharm. Bull. 2008, 56, 1617.

204. Lichitsky, B. V.; Komogortsev, A. N.; Dudinov, A. A.; Krayushkin, M. M. Russ. Chem. Bull. Internation Eddition 2009, 58, 7, 1504.

205. Somayeh, A.; Ramin, G.; Peiman, M.; Ayoob, B. Tetrahedron 2009, 65, 9316.

206. Ayoob, B.; Somayeh, A.; Ramin, G.; Hamid, R. K.; Peiman, M. Ultrasonics Sono. Chem. 2010, $17,447$.

207. Abdel-Latif, F. F. Phosph. Sulfur Silicon 1990, 53, 145.

208. Abdel-Latif, F. F.; Shaker, R. M. Bull. Soc. Chim. Fr. 1991, 127, 87.

209. Al-Thebeiti, M. S. Heterocycles 1998, 48, 145.

210. Joshi, K. C.; Dandia, A.; Khanna, S. Indian J. Chem. 1990, 29B, 1125.

211. Al-Thebeiti, M. S.; El-Zohry, M. F. Heteroatom Chem. 1995, 6, 567.

212. Shemchuk, L. A.; Chernykh, V. P.; Redkin, R. G.; Russ. J. Org. Chem. 2008, 44(12), 1789.

213. Ayoob, B.; Zeinab, N. T.; Peiman, M. Tetrahedron Lett. 2008, 49, 5165.

214. Dandia, A.; Sing, R.; Khaturia, S.; Merienne, C.; Morgant, G.; Loupy, A. Bioorg. Med, Chem. 2006, 14, 2409.

215. Jain, R. Pharmazie 1995, 50, 224.

216. El-Ahl, A. A.; Afeefy, H.; Metwally, M. A. J. Chem. Res. 1994, 14.

217. Joshi, K. C.; Jain, R.; Nishith, S. J. Indian. Chem. Soc. 1990, 67, 490.

218. Joshi, K. C.; Dandia, A.; Beweja, S.; Joshi, A. J. Het. Chem. 1989, 26, 1097.

219. Dandia, A.; Sehgel, V.; Singh, P.; Chem. Pharm. Bull. 1994, 42, 1909.

220. Joshi, K. C.; Jain, R.; Arora, S. J. Fluorin Chem. 1988, 42, 149.

221. Ismail, A. A.; Mona, H. M.; Amr, M. A.; Said, A. S. G. Tetrahedron 2009, 65, 10069.

222. Kempter, G.; Ehrlichmann, W.; Plesse, M.; Lehm, H. U. J. Prakt. Chem. 1982, 324, 832.

223. Kempter, G.; Lehm, H. U.; Plesse, M.; Ehrlichmann, W.; Jumar, A.; Kuehne, S. Ger (East) DD 0412 Oct 1983, 203, 8.

224. Joshi, K. C.; Jain, R.; Sharma, K. Heterocycles 1990, 31, 473.

225. Joshi, K. C.; Dandia, A.; Sanan, S. J. Fluorine Chem. 1989, 44, 59.

226. Joshi, K. C.; Jain, R.; Arora, S. Ind. J. Chem. 1990, 29B, 369.

227. Joshi, K. C.; Dandia, A.; Ahmed, N. Heterocycles 1986, 24, 2479.

228. Popp, F. D.; Rajopadhye, M.; Brown, D. S.; Waddington, D.; Uff, B. C. J. Heterocycl. Chem. 1987, $24,261$.

229. Rajopadhye, M.; Popp, F. D. J. Heterocycl. Chem. 1985, 22, 93.

230. Gaponenko, N. I.; Kolodina, A. A.; Lesin, A. V.; Kurbatov, S. V.; Starikova, Z. A.; Nelyubina, Yu. V. Russ. Chem. Bull. Int. Edi. 2010, 59, 4, 838.

231. Tomchin, A. B.; Marysheva, V. V. Zh. Org. Khim. 1989, 25, 2248.

232. Schulze, A.; Goerdeler, J. Chem. Ber. 1982, 115, 3063.

233. Sharma, R.; Dahiya, R.; Pujari, H. K. Indian J. Chem. 1991, 30B, 508. 